\title{
Hanford Radiological
}

Protection Support Services Annual Report for 1992
M. Lyon
R. K. Piper
D. E. Bihl
T. ). Froelich
1. I. Fix
T. P. Lynch

Juity 1993

Prepared for the U.S. Department of Entergy under Contract DE-AC06-76RLO 1830

Pacific Northwest Laboratory Operated for the U.S. Department of Energy by Battelle Memorial Institute 


\title{
DISCLAIMER
}

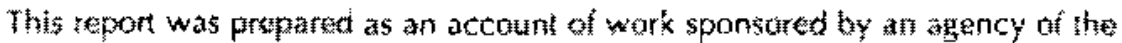

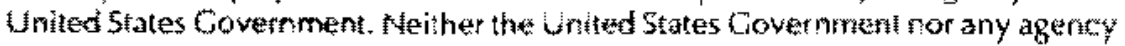
thereof, for Battelle Memotit institute, nor any of their employees, 前akes any warranty, expressed or implied, of assumes any legal hability or respensiblity for the accuracy, completeress, or useiulness of any infomation, apparatus, product, or process tisctosed, or represent that fis use wot d nol infringe privately awned rights. Reference herein to any specific carrmencial product, grocess, or service by

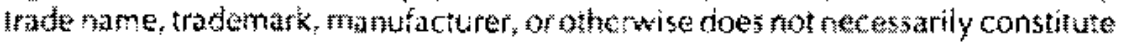
ar mply ts endorsement, recommondation, or favoring by the Inited states Covernment or any agency theredf, or Bottelle memorial Instlute. The views and

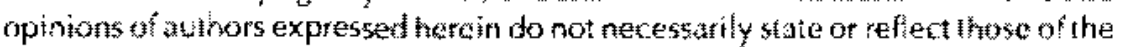

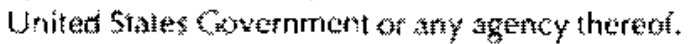

\author{
FACIFIC NORTHWEST IABORATORY \\ operated by \\ BATELEEMEMORIALINSTITUTE \\ Ior the \\ UNITEO STATES DEPARTMENT OF EHERGY \\ wider Contract OE-ACO6-76k1O 1830
}

pringed in the Linited states of Amutica

Available to DOt and DOE contzidtors fram the

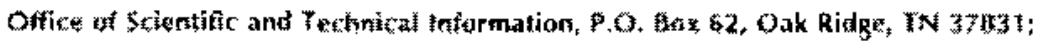

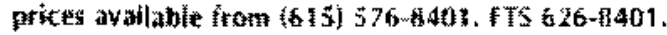

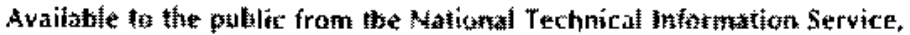

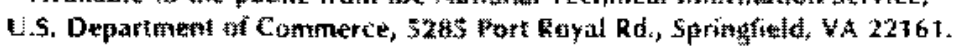


PNL-8764

UC-607

\section{HANFORD RADIOLOGICAL PROTECTION} SUPPORT SERVICES

ANNUAL REPORT FOR 1992
M. Lyon
R. K. Piper
D. E. Bihl
T. J. Froelich
J. J. Fix
T. P. Lynch

July 1993

Prepared for

the U.S. Department of Energy

under Contract DE-AC06-76RLO 1830

Pacific Northwest Laboratory

Richland, Washington 99352 


\begin{abstract}
Various Hanford Site radiation protection services provided by the Pacific Northwest Laboratory for the U.S. Department of Energy Richland Field Office and Hanford contractors are described in this annual report for calendar year 1992. These activities include internal dosimetry measurements and evaluations, in vivo measurements, external dosimetry measurements and evaluations, instrument calibration and evaluation, radiation source calibration, and radiological record keeping. For each of these activities, the routine program and any program changes or enhancements are described, as well as associated tasks, investigations, and studies. Programrelated publications, presentations, and other staff professional activities are also described.
\end{abstract}




\section{SUMMARY}

This report describes certain radiological protection services performed by the Pacific Northwest Laboratory (PNL) during calendar year 1992, in support of the U.S. Department of Energy (DOE) Richland Field Office (RL) and contractor activities on the Hanford Site. These Sitewide services were provided by programs in 1) internal dosimetry, 2) in vivo measurement, 3) external dosimetry, 4) instrument calibration and evaluation, 5) calibration of radiation sources traceable to the National Institute of Standards and Technology (NIST), and 6) radiological records. The routine programs, and any significant program changes, are describsd in this report, along with the supporting studies performed in 1992. Related professional activities, such as publications, presentations, and memberships on standards or industry committees, are also described.

The Hanford Internal Dosimetry Program provides for bioassay monitoring, as well as the associated evaluation and documentation of assessments of internal exposure and dose to Site personnel and visitors. During 1992, the Internal Dosinetry Program performed 9876 excreta bioassay measurements; of these, 185 were assessments of potential new intakes. Approximately 98\% of the measurements were classified as routine, while the remainder were classifted as special-purpose measurements. Supporting tasks that were performed in 1992 included completing the Hanford Internal Dosimeny Procedures Manual, ${ }^{\text {(4) }}$ participating in a DOE-wide intercomparison exercise, and performing independent evaluations of a Savannah River Site exposure. Changes required by the implementation of the Hanford Site Radiological Control Manual, HSRCM-1 (RL 1992), were also made.

The Hantord In Vivo Measurement Program, which provides for the detection of radinactive materials deposited in the Site employes and visitors, is an integral part of personnel dosimetry at Hanford. The program provided 15,417 measurements during 1992. Changes to facilities and equipment included starting up a remotely operated screening counter in the 200 East Area, introducing a new set of algorithms to determine decision levels and activity, and developing and installing a new liquid nitrogen ( $\mathrm{LN}$ ) sensing unit in the counting cells. In addition, a new roof was installed on the 747A Building, a new computer system was procured to support operations of the In Vivo Radioassay and Research Facility, and an agreement was reached for in vivo measurements of U.S. Transuranium Registry donors. Special studies included a study of new detectors with a larger surface area, intercomparison studies of calibration phantoms with the DOE Radiological and Environmental Sciences Laboratory in Idaho, and measurements of ${ }^{137} \mathrm{Cs}$ in caribou meat from eastern Canada.

The Hanford External Dosimetry Program successfully met or exceeded the requitements of three external program reviews during 1992: 1) the routine Westinghouse Hanford Company (WHC) blind-audit dosimeter program; 2) DOE Laboratory Accreditation Ptogram pilot testing of

(a) Ioteraal manual, PNI-MA-S65, Rov, 0, Paeific Norbwest Labomtory, Richland, washington. 
extremity dosimetry performance; and 3) an intercomparison study of environmental dosimeters from Hanford, the states of Washington and Oregon, the Washington Public Power Supply System, and the U.S. Nuclear Regulatory Commission. During the year, 203,225 dosimeters were processed, and dose-of-record information was reported to the Hanford Radiological Records Program for 90,302 personnel dosimeters. Two changes were made in the routine calculation of personnel dose: an improved dose algorithm was implemented (effective January 1992) and lower detection levels were calculated for each routine dosimeter processing. The three supporting studies that were conducted involved 1) changing the code support for nuclear accident dosimeters to the VAX computer; 2) continuing the measurements of neutron dose for a few selected personnel, using a prototype combination thermoluminescent/ track-etch personnel neutron dosimeter; and 3) documenting quality-control procedures for dosimetry processing in a PNL technical report. Procurement of a commercial thermoluminescent dosimetry (TLD) system, consisting of personnel, extremity, and environmental dosimeters, was finalized during October 1992. Fabrication of a track-etch dosimetry (TED) counting system in the 318 Building was also completed during 1992.

To ensure personnel safety in the Hanford workplace, the Instrument Calibration and Evaluation Program provides Site contractors with complete and reliable services for radiation protection instruments. Specific tasks performed under this program during 1992 included conducting the routine instrument pool, administering the Hanford Instrument Evaluation Program, calibrating alpha continuous air monitors (CAMs) in the WHC 200 Area, and testing and evaluating a new generation of alpha CAMs. Other tasks performed in 1992 included developing program policy with the evolution and issuance of the DOE Radiological Control Manual (1992), completing the initial drafts of instructions and user specifications for both alpha and beta CAMs for the Site Radiation Protection Instrument Manual ${ }^{\text {a) }}$; and providing technical review and assistance in the revision of WHC CAM calibration procedures. The Instrument Calibration and Evaluation Program also assumed direct support for the HP-9000 database that contains all instrument calibration records.

The Radiation Standards and Calibrations Project maintains radiological standards necessary for appropriate characterizations and calibrations within the Hanford Instrument Calibration and External Dosimetry Programs. The Project maintains special equipment for characterizing instrument and dosimeter response, and supplemental radiological reference fields, as necessary. This activity provides the means to characterize response to various radiation fields encountered at Hanford, and ensures that calibration fields are described in accordance with recommended standards and guides. Highlights for 1992 included the successful completion of measurement quality assurance (MQA) interactions with NIST, which were necessary to corroborate traceability in photon and beta particle measurements. These MQA interactions were necessary to corroborate traceability. In addition, calibration was completed for a high-energy photon

(a) Internal manual, PNL-MA-562, Pacific Northwest Laboratory, Richland, Washington. 
irradiation source capable of providing exposure rates in the micro-roentgen per hour range. Special studies included investigating a new tissue-equivalent proportional counter that has potential for use as a valid neutron intercomparison device, and investigating the effects of phantom size on the response of various dosimeters exposed to neutrons.

Since the inception of Hanford in the early 1940s, the Hanford Radiological Records Program has preserved and administered all records of personnel radiological exposyre, and of Hanford historical radiation protection and radiological dosimetry practices. During 1992, the Radiological Records Program operated the Occupational Radiation Exposure (ORE) system and maintained the Hanford Radiation Protection Historical Files, in support of the RL and Hanford contractor radiological protection and dosimetry programs. In addition to producing reports for RL, DOE Headquarters, Site contractors, and individuals, the program assisted epidemiology and Site historical research projects. Development of the Radiological Exposure (REX) system continued during the year. The REX development project completed the Detailed Design and Construction phase and entered the Implementation phase, which continued for the remainder of the year. In addition, the laser optical disk subsystem (LaserREX) was procured, installed, and started up. New data lines were also installed to accept data from the new analytical laboratory, and some program changes were made in response to the newly implemented HSRCM-1

(RL 1992). 



\section{ACKNOWLEDGMENTS}

The authors would like to thank the staff members whose professional skills and technical expertise ensure the success of the Hanford External Dosimetry Program, Internal Dosimetry Program, In Vivo Measurement Program, Instrument Calibration Program, Radiological Records Program, and Radiation Standards and Calibrations Project. 

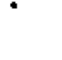


\section{ACRONYMS AND ABBREVIATIONS}

ACL

AEDE

ANSI

BCSR

BOMAB

BRMD

CAM

CAR

CEDE

CEDR

CINDY

CP

CY

DBMS

DEC

DOE

DOELAP

EDF

FY

GM

HDPE

HEHF

HIEC

HP

HRRP

HSRCM

IARC

IDP

ITAS

ITRI

IU

IVRRF

$\mathrm{KEH}$
Analytical Chemistry Laboratory

annual effective dose equivalent

American National Standards Institute

Boeing Computer Services - Richland

Bottle Manikin Absorption (phantom)

Bureau of Radiation and Medical Devices

continuous air monitor

computer-assisted retrieval

committed effective dose equivalent

Comprehensive Epidemiologic Data Resource

Code for Internal Dosimetry

cutie pie

calendar year

database management software

Digital Equipment Corporation

U.S. Department of Energy

DOE Laboratory Accreditation Program

Emergency Decontamination Facility

fiscal year

Geiger-Mueller

high density polyethylene

Hanford Environmental Health Foundation

Hanford Instrument Evaluation Committee

Hewlett Packard

Hanford Radiological Records Program

Hanford Site Radiological Control Manual

International Agency for Research on Cancer

Hanford Internal Dosimetry Program

International Technology Analytical Services

Inhalation Toxicology Research Institute

isotopic uranium

In Vivo Radioassay and Research Facility

Kaiser Engineers Hanford Company 


$\begin{array}{ll}\text { LANL } & \text { Los Alamos National Laboratory } \\ \text { LN } & \text { liquid nitrogen } \\ \text { LOD } & \text { laser optical disk } \\ \text { LSIS } & \text { Large Scale Information System (NSAS 9080 mainframe) } \\ \text { MCA } & \text { multichannel analyzer } \\ \text { MDA } & \text { minimum detectable activity } \\ \text { MO } & \text { magneto-optical disk drive } \\ \text { MQA } & \text { measurement quality assurance } \\ \text { mrem } & \text { millirem } \\ \text { NAD } & \text { nuclear accident dosimeter } \\ \text { NIST } & \text { National Institute of Standards and Technology (previously called the } \\ \text { NMC } & \text { National Bureau of Standards, NBS) } \\ \text { ORE } & \text { Nuclear Measurements Corporation } \\ \text { ORNL } & \text { Occupational Radiation Exposure (system) } \\ \text { PAM } & \text { Oak Ridge National Laboratory } \\ \text { PC } & \text { portable alpha monitor } \\ \text { PNL } & \text { personal computer } \\ \text { PRF } & \text { Pacific Northwest Laboratory } \\ & \text { Platinum Report Facility } \\ \text { QA } & \text { quality assurance } \\ \text { QC } & \text { quality control } \\ \text { QUS } & \text { quick uranium soluble } \\ \text { RESL } & \text { DOE Radiological and Environmental Sciences Laboratory } \\ \text { REX } & \text { Radiation Exposure (system) } \\ \text { RL } & \text { DOE Richland Field Office } \\ \text { ROI } & \text { region of interest } \\ \text { RPT } & \text { radiation protection technologist } \\ \text { RS\&C } & \text { Radiation Standards and Calibrations (Project) } \\ \text { RTL } & \text { Research Technology Laboratory } \\ \text { SDD } & \text { Software Design Document } \\ \text { SOW } & \text { Statement of Work } \\ \text { SQL } & \text { Standard Query Language } \\ \text { TED } & \text { tracketch dosimetry (system) } \\ \text { TEPC } & \text { tissue equivalent proportional counter } \\ \text { TLD } & \text { thermoluminescent dosimetry (system) } \\ \text { TMA } & \text { transuranic (radionuclides) } \\ \text { TRU } & \end{array}$




$\begin{array}{ll}\text { USDT } & \text { U.S. Dosimetry Technology } \\ \text { UST } & \text { U.S. Testing, Inc. } \\ \text { USTR/USUR } & \begin{array}{l}\text { U.S. Transuranium Registry/U.S. Uranium Registry } \\ \text { ultraviolet }\end{array} \\ \text { UV } & \\ \text { WBC } & \text { whole-body count } \\ \text { WHC } & \text { Westinghouse Hanford Company } \\ \text { WORM } & \text { write-once/read-many } \\ \text { WSU } & \text { Washington State University }\end{array}$





\section{CONIENTS}

ABSTRACT $\ldots \ldots \ldots \ldots, \ldots \ldots \ldots \ldots \ldots \ldots, \ldots \ldots$, iii

SUMMARY $\ldots \ldots \ldots \ldots \ldots \ldots \ldots \ldots \ldots \ldots \ldots \ldots \ldots, \ldots \ldots, \ldots \ldots$

ACKNOWLEDGMENTS $\ldots \ldots \ldots \ldots \ldots \ldots \ldots \ldots$ ix

ACRONYMS AND ABBREVIATIONS $\ldots \ldots \ldots \ldots \ldots \ldots \ldots \ldots \ldots$ xi

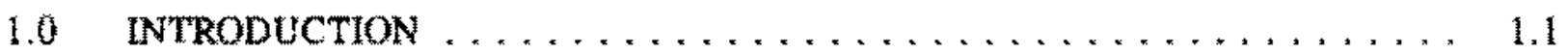

2.0 HANFORD INTERNAL DOSIMETRY PROGRAM $\ldots \ldots \ldots \ldots \ldots \ldots 2.1$

2.1 THE ROUTINE PROGRAM $\ldots \ldots \ldots \ldots \ldots \ldots \ldots \ldots \ldots \ldots \ldots . .1$

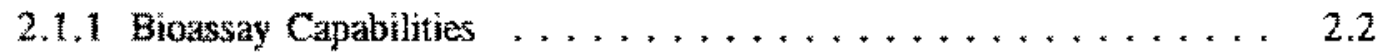

2.1 .2 Excreta Bioassay Contract Status $\ldots \ldots \ldots \ldots \ldots \ldots \ldots$

2.1 .3 Excreta QC Oversight Program $\ldots \ldots \ldots \ldots \ldots \ldots \ldots$

2.1 .4 Program Change Records $\ldots \ldots \ldots \ldots \ldots \ldots \ldots \ldots \ldots . .7$

2.1.5 Program Changes in Response to the DOE

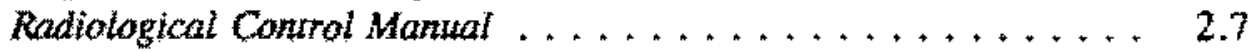

2.1.6 The Honfon Intemal Dosimetry Procedures Manual $\ldots \ldots \ldots \ldots 2.8$

2.2 MONITORING AND ASSESSMENT ACTIVITIES $\ldots \ldots \ldots \ldots \ldots 2.9$

2.2 .1 Excreta Bioassay Monitoring Activities $\ldots \ldots \ldots \ldots \ldots \ldots$

2.2 .2 Internal Dose Assessment Activities $\ldots \ldots \ldots \ldots \ldots \ldots \ldots 2.12$

2.3 SUPPORTING STUDIES $\ldots \ldots \ldots \ldots \ldots \ldots \ldots \ldots \ldots \ldots \ldots, 2.17$

2.4 PROGRAM-RELATED PROFESSIONAL ACTIVITIES $\ldots \ldots \ldots \ldots 2.18$

2.4 .1 Presentations $\ldots \ldots \ldots \ldots \ldots \ldots \ldots \ldots \ldots \ldots \ldots \ldots . \ldots \ldots$

2.4.2 Professional Memberships $\ldots \ldots \ldots \ldots \ldots \ldots \ldots \ldots \ldots, 2.19$

3.0 HANFORD IN VIVO MEASUREMENT PROGRAM $\ldots \ldots \ldots \ldots \ldots \ldots 3.1$

3.1 THE ROUTINE PROGRAM $\ldots \ldots \ldots \ldots \ldots \ldots \ldots \ldots \ldots . .1$ 
3.1.1 Routine In Vivo Measurements $\ldots \ldots \ldots \ldots \ldots \ldots \ldots .3 .1$

3.1 .2 Remote Counter $\ldots \ldots \ldots \ldots \ldots \ldots \ldots \ldots \ldots . .2$

3.1.3 Number of Measurements Performed $\ldots \ldots \ldots \ldots \ldots . \ldots .2$

3.1.4 Preparation for DOELAP Accreditation $\ldots \ldots \ldots \ldots \ldots \ldots .4$

3.2 ADDITIONS OR CHANGES TO EQUIPMENT AND FACILITIES $\ldots . .3 .4$

3.2.1 New Algorithms for IVRRF $L_{c}$ and Measurements $\ldots \ldots \ldots 3.5$

3.2.2 New Image Analysis Procedure $\ldots \ldots \ldots \ldots \ldots \ldots \ldots$

3.2.3 Counting Cell Safety $\ldots \ldots \ldots \ldots \ldots \ldots \ldots \ldots$

3.2.4 New Computer System for IVRRF Operations $\ldots \ldots \ldots \ldots \ldots 3.6$

3.2.5 New Roof for the 747 A Building $\ldots \ldots \ldots \ldots \ldots \ldots \ldots .7$

3.2.6 DOE Phantom Library $\ldots \ldots \ldots \ldots \ldots \ldots \ldots \ldots$

3.3 SUPPORTING STUDIES $\ldots \ldots \ldots \ldots \ldots \ldots \ldots \ldots \ldots \ldots .7$

3.3.1 Phantom Measurement Study $\ldots \ldots \ldots \ldots \ldots \ldots \ldots .7$

3.3.2 U.S. Transuranium Registry Support . . . . . . . . . . . . . 3.9

3.3.3 Detector Upgrades for Lung Counting $\ldots \ldots \ldots \ldots \ldots \ldots . .9$

3.3.4 Intercomparisons of Calibration Phantoms $\ldots \ldots \ldots \ldots \ldots .9 .9$

3.3.5 Caribou Meat Measurements for ${ }^{137} \mathrm{Cs} \ldots \ldots \ldots \ldots \ldots \ldots$

3.4 PROGRAM-RELATED PROFESSIONAL ACTIVITIES $\ldots \ldots \ldots \ldots 3.10$

3.4 .1 Presentations $\ldots \ldots \ldots \ldots \ldots \ldots \ldots \ldots \ldots \ldots \ldots \ldots \ldots$

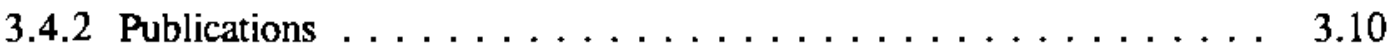

3.4.3 Professional Memberships $\ldots \ldots \ldots \ldots \ldots \ldots \ldots \ldots \ldots .3 .10$

4.0 HANFORD EXTERNAL DOSIMETRY PROGRAM $\ldots \ldots \ldots \ldots \ldots \ldots .4$

4.1 EXTERNAL PERFORMANCE TESTING EVALUATIONS $\ldots \ldots \ldots 4.1$ 
4.1 .1 WHC Blind Audit Dosimeters . . . . . . . . . . . . 4.1

4.1.2 DOELAP Extremity Dosimetry Testing . . . . . . . . . . 4.1

4.1.3 Environmental Intercomparison Study . . . . . . . . . . . . 4.2

4.2 THE ROUTINE PROGRAM $\ldots \ldots \ldots \ldots \ldots \ldots \ldots \ldots \ldots \ldots$

4.2 .1 Routine Processing . . . . . . . . . . . . . . . . 4.2

4.2.2 Implementation of 1991 DOELAP-Tested Algorithm . . . . . . . . 4.4

4.2.3 Code Modifications for Lower-Level-

of-Detection Analysis $\ldots \ldots \ldots \ldots . \ldots . \ldots . \ldots . \ldots 4$

4.2.4 Plan for Updating Nuclear Accident

Documentation Dosimetry ................. . 4.5

4.2 .5 Revised Documentation . . . . . . . . . . . . . 4.5

4.3 NEW THERMOLUMINESCENT AND TRACK-ETCH DOSIMETRY

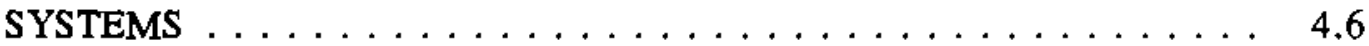

4.3.1 Thermoluminescent Dosimetry System . . . . . . . . . . . . 4.6

4.3.2 Track-Etch Dosimetry System . . . . . . . . . . . . . . 4.6

$4.4 \quad$ SUPPORTING STUDIES $\ldots \ldots \ldots \ldots \ldots \ldots \ldots \ldots \ldots$

4.4.1 Nuclear Accident Dosimetry . . . . . . . . . . . . . . 4.6

4.4.2 Prototype Combination TLD/TED Personnel

Neutron Dosimeters . . . . . . . . . . . . . . . . . . . 4.7

4.3.3 Quality Control Report $\ldots \ldots \ldots \ldots \ldots \ldots . \ldots \ldots . \ldots \ldots$

4.5 PROGRAM-RELATED PROFESSIONAL ACTIVITIES $\ldots \ldots \ldots \ldots$

4.5 .1 Presentations $\ldots \ldots \ldots \ldots \ldots \ldots \ldots \ldots \ldots$

4.5 .2 Publications $\ldots \ldots \ldots \ldots \ldots \ldots \ldots \ldots \ldots \ldots$

4.5 .3 Professional Memberships $\ldots \ldots \ldots \ldots \ldots$

5.0 INSTRUMENT CALIBRATION AND EVALUATION PROGRAM $\ldots \ldots \ldots$. 
5.1 THE ROUTINE PROGRAM $\ldots \ldots \ldots \ldots \ldots \ldots \ldots \ldots \ldots . \ldots .1$

5.1 .1 Routine Portable Instrument Pool $\ldots \ldots \ldots \ldots \ldots \ldots .2$

5.1.2 Hanford Instrument Evaluation Program $\ldots \ldots \ldots \ldots \ldots . .4$

5.1.3 Calibration of WHC 200-Area Alpha CAMs $\ldots \ldots \ldots \ldots . \ldots$

5.1 .4 Instrument Manual Update $\ldots \ldots \ldots \ldots \ldots \ldots \ldots \ldots . . \ldots .4$

$5.2 \quad$ PROGRAM CHANGES IN $1992 \ldots \ldots \ldots \ldots \ldots \ldots \ldots \ldots$

5.2.1 Calibration and Evaluation Program Policy Development $\ldots \ldots \quad 5.5$

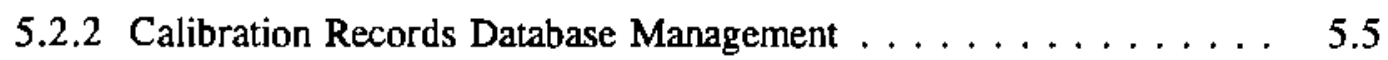

5.3 SUPPORTING STUDIES $\ldots \ldots \ldots \ldots \ldots \ldots \ldots \ldots \ldots$

5.3.1 Testing and Evaluation of a New Generation

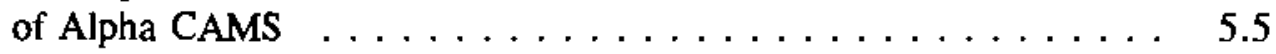

5.3.2 Technical Review of WHC CAM Calibration Procedures $\ldots \ldots \quad 5.6$

5.4 PROGRAM-RELATED PROFESSIONAL ACTIVITIES $\ldots \ldots \ldots \ldots .6$

6.0 RADIATION STANDARDS AND CALIBRATIONS PROJECT $\ldots \ldots \ldots \ldots 6.1$

6.1 THE ROUTINE PROGRAM $\ldots \ldots \ldots \ldots \ldots \ldots \ldots \ldots \ldots$

6.1 .1 Standards and Capabilities $\ldots \ldots \ldots \ldots \ldots \ldots \ldots . \ldots \ldots$

6.1 .2 Calibrations and Constancy Checks $\ldots \ldots \ldots \ldots \ldots \ldots$

6.1 .3 Measurement Quality Assurance $\ldots \ldots \ldots \ldots \ldots \ldots \ldots .6$

6.1.4 Improvements to Standards and Capabilities $\ldots \ldots \ldots \ldots .6 .9$

6.2 SUPPORTING STUDIES $\ldots \ldots \ldots \ldots \ldots \ldots \ldots \ldots \ldots$

7.0 HANFORD RADIOLOGICAL RECORDS PROGRAM $\ldots \ldots \ldots \ldots \ldots \ldots .1$

7.1 THE ROUTINE PROGRAM $\ldots \ldots \ldots \ldots \ldots \ldots \ldots \ldots \ldots .2$

7.2 SUPPORTING TASKS $\ldots \ldots \ldots \ldots \ldots \ldots \ldots \ldots \ldots \ldots$

7.2.1 Development of the REX System $\ldots \ldots \ldots \ldots \ldots \ldots \ldots$ 
7.2 .2 Laser Optical Disk Subsystem . . . . . . . . . . . . . 7.6

7.3 PROGRAM-RELATED PROFESSIONAL ACTIVITIES $\ldots \ldots \ldots \ldots$

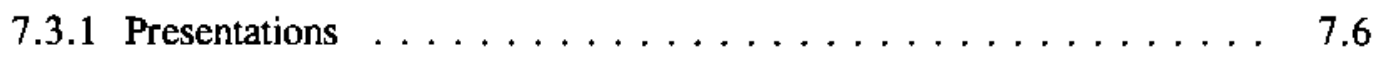

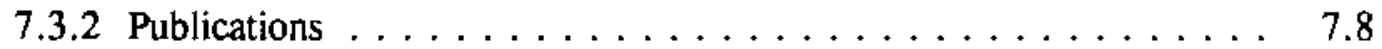

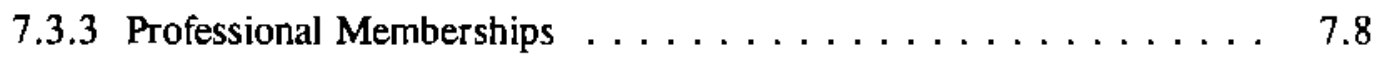

$8.0 \quad$ REFERENCES $\ldots \ldots \ldots \ldots \ldots \ldots \ldots \ldots \ldots \ldots \ldots \ldots \ldots$ 


\section{FIGURES}

1.1 Management Structure and Major Communication Interfaces for Hanford Radiological Support Services . . . . . . . . . . . . . . . . . 1.2

2.1 Standard and Nonstandard Excreta Requests by Month . . . . . . . . . . . . 2.10

2.2 Routine Urine Measurements Made from 1986 Through $1991 \ldots \ldots . . \ldots$. . . . . 2.12

3.1 In Vivo Measurements Made at the IVRRF from 1987 Through $1992 \ldots \ldots .4$

3.2 Various In Vivo Calibration Phantoms Available

from the DOE Phantom Library, Administered by PNL $\ldots \ldots \ldots \ldots \ldots$

6.1 Typical Calibration well $\ldots \ldots \ldots \ldots \ldots \ldots \ldots \ldots$

6.2 Bremsstrahlung X-Ray Spectrum (M30 Technique, April 1992) $\ldots \ldots \ldots .4$

6.3 K-Fluorescence X-Ray Spectrum (K59 Technique, April 1992) . . . . . . . . 6.4

7.1 The Laser Optical Disk Subsystem $\ldots \ldots \ldots \ldots \ldots \ldots \ldots \ldots$ 


\section{TABLES}

2.1 Speciffed Minimum Detectable Activities and Screering Levels for Routine Excreta Analyses During $1992 \ldots \ldots \ldots \ldots$

2.2 Minimum Detectable Activities and Screening Levels

for Routine In Vivo Measurements During $1992 \ldots \ldots \ldots \ldots \ldots \ldots$

2.3 Specifed Minimum Detectable Activities for Emergency and Expedited Excreta Bioassay During $1992 \ldots \ldots \ldots \ldots \ldots \ldots .2 .5$

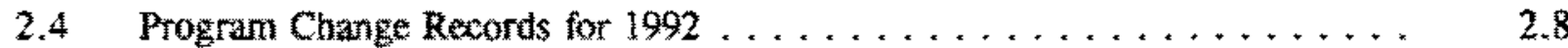

2.5 Worker Excreta Measurements Reported for 1992 Samples $\ldots \ldots \ldots \ldots .2 .11$

2.6 Summary of Potential Exposure incidents During $1992 \ldots \ldots \ldots \ldots .2 .13$

2.7 Comparison of Internal Exposure Incidents and Internal Exposure Dose Assessments, $1988-1992 \ldots \ldots \ldots \ldots . \ldots . . .14$

2.8 Summary of Confirmed Intake Cases Identified Through the Routine Bioassay Program During $1992 \ldots \ldots \ldots \ldots \ldots \ldots \ldots \ldots$.

2.9 Internal Dose Status of the Hanford Work Force at 1992 Year End $\ldots \ldots \ldots \ldots \ldots \ldots \ldots \ldots \ldots \ldots \ldots \ldots \ldots$

2.10 Intercomparison of ${ }^{238}$ Pu Inhalation Dose Assessment $\ldots \ldots \ldots \ldots \ldots, 2.18$

3.1 In Vivo Measurements Performed During 1992 and Recorded in the ORE Database $\ldots \ldots \ldots \ldots \ldots \ldots \ldots \ldots . \ldots \ldots$

4.1 Calibration Factors for Hanford Extremity Dosimeter $\ldots \ldots \ldots \ldots \ldots$. 4.2

4.2 Personnel Dosimeters Processed During $1992 \ldots \ldots \ldots \ldots \ldots \ldots \ldots$

4.3 Audit Dosimeters Processed During $1992 \ldots \ldots \ldots \ldots \ldots \ldots \ldots$

5.1 Portable Instrument Use by Hanford Contractors in $1992 \ldots \ldots \ldots . . . .5$

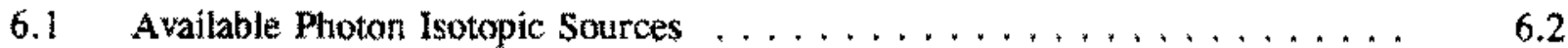

6.2 Available $\mathrm{X}$-Ray Photon Techniques $\ldots \ldots \ldots \ldots \ldots \ldots \ldots . \ldots \ldots$

6.3 Photon Reference Fields-Calibration Performance Summary . . . . . . 6.7

6.4 Beta MQA Performance Summary $\ldots \ldots \ldots \ldots \ldots \ldots \ldots \ldots \ldots . \ldots \ldots$ 
6.5 Photon MQA Intercomparison Summary $\ldots \ldots \ldots \ldots . \ldots \ldots$

$7.1 \quad$ Records Activity for $1992 \ldots \ldots \ldots \ldots \ldots \ldots \ldots$ 


\subsection{INTRODUCTION}

This annual report documents the calendar year (CY) 1992 activities of specific radiation protection services performed by the Pacific Northwest Laboratory (PNL) ${ }^{(a)}$ for the U.S. Department of Energy (DOE) Richland Field Office (RL) and the Hanford Site contractors. These Sitewide services are provided by programs in 1) internal dosimetry, 2) in vivo measurement, 3) external dosimetry, 4) instrument calibration and evaluation, 5) calibration of radiation sources traceable to the National Institute of Science and Technology (NIST), and 6) radiological records. All of these services fall within the purview of the PNL Health Physics Department.

Although some of the programs described in this report are involved in activities funded by other sources, only those activities funded by RL, DOE Headquarters, or the Hanford contractors are addressed here. Services provided for non-RL activities are performed only to the extent that they do not adversely affect services to DOE and its contractors. These non-RL services provide funds that support the overall program and reduce costs to DOE. They also reduce costs to the Hanford contractors, which comprise Boeing Computer Services - Richland (BCSR), the Hanford Environmental Health Foundation (HEHF), Kaiser Engineers Hanford Company (KEH), PNL, and Westinghouse Hanford Company (WHC).

Each of the six Hanford programs is described in a separate section of this report. Program descriptions include

- the routine program, including any significant changes or improvements;

- investigations, studies, and tasks performed in support of the routine program; and

- other program-related activities, such as publications, presentations, and professional memberships.

The PNL and DOE management structure and communication interfaces for each PNL-operated program are shown in the organizational chart in Figure 1.1. The DOE Safety and Environmental Division is responsible for PNL services in this area.

(a) Pacific Northwest Laboratory is operated by Battelle Memorial Institute for the U.S. Department of Energy under Contract DE-AC06-76RLO 1830. 


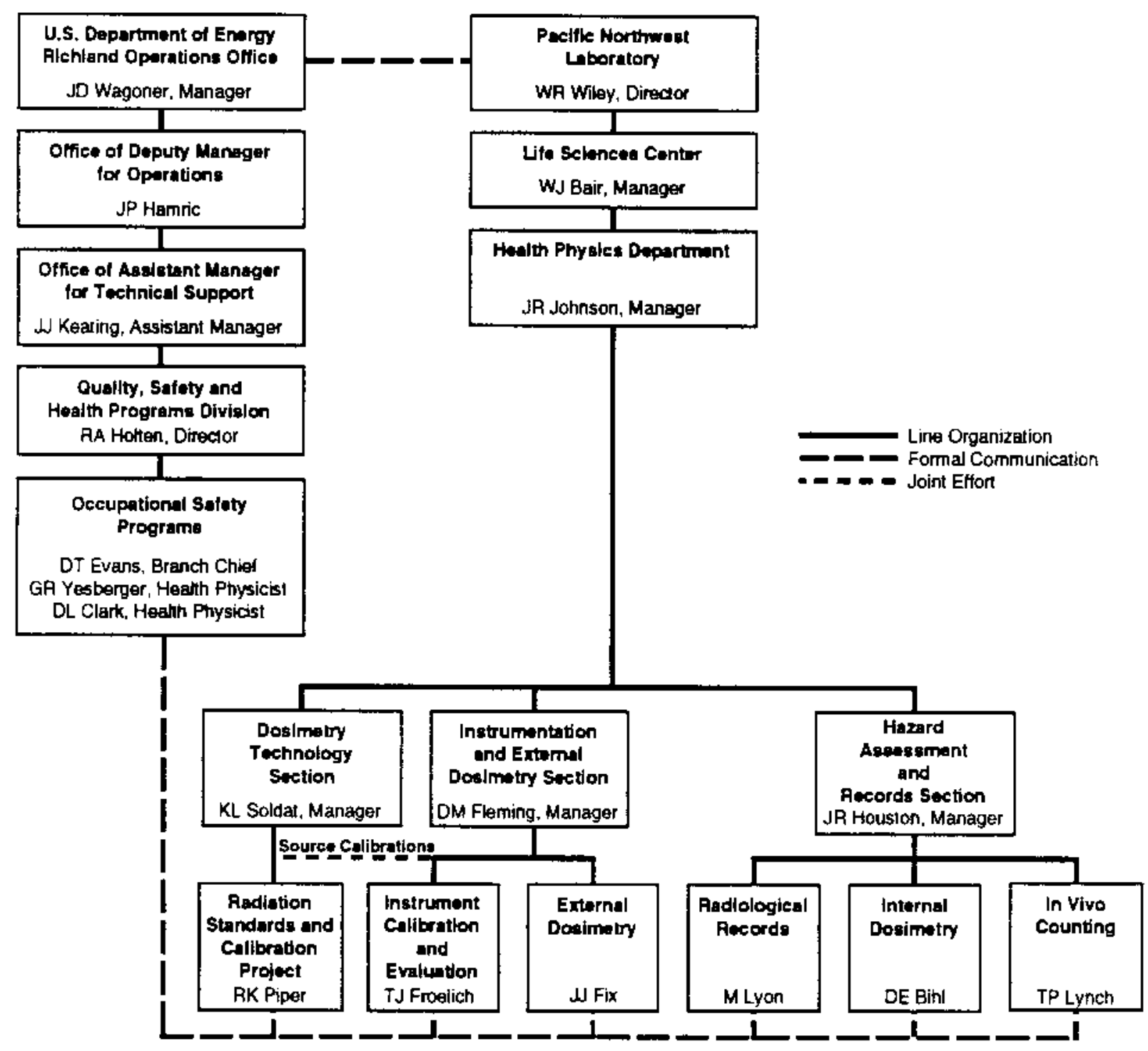

59305057.4

Figure 1.1. Management Structure and Major Communication Interfaces for Hanford Radiological Support Services 


\subsection{HANFORD INTERNAL DOSIMETRY PROGRAM}

The Hanford Internal Dosimetry Program (IDP) was initiated in 1946 to provide for the assessment and documentation of occupational doses from intakes of radionuclides at the Hanford Site. The program is administered in support of Hanford radiation protection programs, as required by DOE 5480.11, "Radiation Protection for Occupational Workers" (1990); the Hanford Site Radiological Control Manual, HSRCM-1 (RL 1992); and the Hanford Site Services Handbook. ${ }^{\text {(a) }}$ The program provides the following internal dosimetry services:

- administration of a routine bioassay monitoring program;

- investigation and assessment of potential internal exposures;

- monitoring performance of the excreta bioassay laboratories;

- $\quad$ selection and application of models, procedures, and practices for evaluating internal exposures;

- technical support to DOE Richland Field Office (RL) and to Site contractors; and

- 24-hour, single-point-of-contact technical support for radiological incidents at Hanford.

\subsection{THE ROUTINE PROGRAM}

Intakes of radionuclides are generally prevented by containment or other protective measures; therefore, intakes are generally assumed to result from an acute intake. Dose assessment is based on this assumption, although exceptions occur for work with tritium and uranium. Tritium intake is generally assumed to occur chronically throughout the period of exposure, so assessment of work in the hot cell in the 324 Building was planned accordingly. Because entries into the hot cell did not occur daily, samples were taken the day or so after each entry and an acute intake scenario was assumed. For years, chronic exposure conditions were also assumed for uranium work. However, with the changing mission at Hanford and increased emphasis on reducing intakes, the assumed nature of exposure to uranium changed. Many WHC workers were placed on quarterly, as opposed to monthly, uranium urinalysis because they rarely entered uranium contaminated zones. Their urinalysis results were interpreted assuming a possible acute intake. During decontamination of the uranyl nitrate load-out facility at PUREX (203A), workers entered the facility often. Because respiratory protection was required for all work, however, a possible acute intake was assumed for those workers.

(a) U.S. Department of Energy Richland Field Office (RL), 1993, RL 1400.1A, Rjchland, Washington (avajlable online in HanInfo). 
Operation of the IDP is described in the following documents:

- the technical aspects of internal dose calculations are established in the Technical Basis for Internal Dosimetry at Hanford (Sula, Carbaugh, and Bihl 1991);

- the protocols and practices for operation of the program and coordination with the Site contractors are established in the Hanford Internal Dosimetry Program Manual (a);

- detailed procedures are contained in the Hanford Internal Dosimetry Procedures Manual ${ }^{(b)}$; and

- the technical agreements with the excreta lab are established by a Statement of Work.

The practices and technical aspects of operating the Hanford In Vivo Measurement Program are established in the Whole Body Counting Manual, ${ }^{(c)}$ and were supplemented in May 1992 by the "In Vivo Bioassay Statement of Work. " ${ }^{\text {(d) }}$ Individual assessments of internal dose are documented in each individual's file in the Hanford Radiological Records Program microfilm files. Bioassay measurement results are maintained in the ORE database, which is operated by the Radiological Records Program.

\subsubsection{Bioassay Capabilities}

Bioassay monitoring is performed regularly for workers who might inhale, ingest, or absorb radionuclides into their bodies in the course of their jobs. Measurement types and frequencies are based on the radionuclides of concern and their anticipated physical and chemical form. Minimum detectable activities (MDAs) and follow-up levels for routine excreta and in vivo bioassay measurements are shown in Tables 2.1 and 2.2. MDAs for other categories of excreta analyses are shown in Table 2.3. The excreta MDAs were unchanged from those listed for the permanent contract in 1991. The in vivo MDAs, however, underwent a major change at the start of 1992, as explained in the following chapter on the Hanford In Vivo Measurement Program (see section 3.2.1, "New Algorithms for the IVRRF $L_{c}$ and Measurements"). New excreta screening levels were established for certain uranium exposure conditions and for tritium exposure for the hot cell clean-out in the 324 Building.

(a) Internal manual, PNL-MA-552, Pacific Northwest Laboratory, Richland, Washington.

(b) Internal manual, PNL-MA-565, Rev. 0, Pacific Northwest Laboratory, Richland, Washington.

(c) Internal manual, PNL-MA-574, Pacific Northwest Laboratory, Richland, Washington.

(d) T. P. Lynch, J. A. MacLellan, and D. E. Bihl. 1992. "In Vivo Bioassay Statement of Work." (A copy is available in the Hanford Radiation Protection Historical Files.) 
Table 2.1. Specifed Minimum Detectable Activities and Screening Levels for Routine Excreta Analyses During 1992

\begin{tabular}{|c|c|c|}
\hline Analysis $^{(a)}$ & Contractual $\mathrm{MDA}^{(\mathrm{b}, \mathrm{c})}$ & $\begin{array}{l}\text { Screening Level and } \\
\text { Sampling Frequency }(c, d)\end{array}$ \\
\hline${ }^{233} \mathrm{Pu},{ }^{239} \mathrm{Pu}$ & $0.02 \mathrm{dpm}$ & $0.01 \mathrm{dpm}(\mathrm{A})$ \\
\hline $\mathrm{sit}_{\mathrm{sr}}$ & $10 \mathrm{dpm}$ & $\begin{array}{l}26 \mathrm{dpm}(\mathrm{A}) \\
11 \mathrm{dpm}(\mathrm{BE})\end{array}$ \\
\hline${ }^{234} \mathrm{U},{ }^{23 \mathrm{~B}} \mathrm{U}$ & $0.02 \mathrm{dpm}$ & $\begin{array}{l}0.15 \mathrm{dpm}(\mathrm{A}, Q)^{(\mathrm{c}, \mathrm{f})} \\
0.40 \mathrm{dpm}(Q)^{(\mathrm{g})}\end{array}$ \\
\hline${ }^{235} \mathrm{U}$ & $0.02 \mathrm{dpm}$ & $\begin{array}{l}0.01(A) \\
0.02 \mathrm{dpm}(Q)\end{array}$ \\
\hline${ }^{24} \mathrm{Am}_{*}{ }^{242} \mathrm{Cm}$ & $0.02 \mathrm{dpm}$ & $0.01 \mathrm{dpm}(\mathrm{A})$ \\
\hline Elemental U & $0.06 \mu \mathrm{g}$ & $\begin{array}{l}0.2 \mu \mathrm{g}(\mathrm{Q})^{(\mathrm{e}) \bar{t}} \\
0.5 \mu \mathrm{g}\left(\mathrm{Q}^{(\mathrm{k})}\right.\end{array}$ \\
\hline Elemental U (QUS) & $0.5 \mu \mathrm{g}$ & $\begin{array}{l}11 \mu \mathrm{g}(\mathrm{BW}) \\
1 \mu \mathrm{g}(\mathrm{M})^{(\mathrm{f})} \\
4 \mu \mathrm{g}(\mathrm{M})^{(\mathrm{g})}\end{array}$ \\
\hline Tritium & $20 \mathrm{dpm} / \mathrm{mL}$ & $80 \mathrm{dpm} / \mathrm{mL}^{(\mathrm{b})}$ \\
\hline
\end{tabular}

(a) Analysis of urine samplez, whless otherwise indioted.

(b) Specified MDA based on Type I and Type II errors of 5 , as described in the SOW (a copy is arallable in the Hanford Radiation Protetion Historical Files).

(c) Amount per total sample volume, unless otherwise indicated.

(d) Investigation of a potential internal exposure is performed when this value is exceeded (routine bioassay monitoring frequency: Amannual, BE-biennial, BW-biweekly, M-monthly, Q-quarterly).

(e) Upper level of expected environmentally derived uranium in urine for the Hanford region.

(f) When this level is exceeded, the worker's results are evaluated at the end of the year for possible chronic intake.

(g) When this level is exeded, an inmediate investigation for a possible actute intate is started.

(h) Special screening levels were established for the tritum cell clean-out work in the 324 Building because of acute exposure conditions and shor times between exposure and sampling. These levels were documented in Program Change Record 92-004. 
Table 2.2. Minimum Detectable Activities and Screening Levels for Routine In Vivo Measurements During 1992

\begin{tabular}{lcc}
\hline Measurement/Radionuclide ${ }^{(a)}$ & $\begin{array}{l}\text { MDA } \\
(\mathrm{nCi})\end{array}$ & $\begin{array}{c}\text { Screening Level }{ }^{(\mathrm{b})} \\
(\mathrm{nCi})\end{array}$ \\
\hline Whole-Body Count ${ }^{(\mathrm{c})}$ & & \\
${ }^{60} \mathrm{Co}$ & 6 & 8 \\
${ }^{154} \mathrm{Eu}$ & 12 & 8 \\
${ }^{137} \mathrm{Cs}$ & 3 & 9 \\
Lung Count & & \\
${ }^{235} \mathrm{U}$ & 0.2 & Any detected \\
${ }^{238} \mathrm{U}$ (by $\left.{ }^{234} \mathrm{Th}\right)$ & 3 & Any detected \\
${ }^{241} \mathrm{Am}$ & 0.12 & Any detected \\
& & \\
\hline
\end{tabular}

(a) For selected radionuclides. (The detection of radionuclides not listed resulted in follow-up.)

(b) Level for which an investigation of internal exposure was considered. Any detected activity above background (i.e., above the decision level) was reported to the IDP.

(c) MDAs apply to the preview counter only; much lower MDAs were obtained using the germanium array when activity was first detected using the preview counter. 
Table 2.3. Specified Minimum Detectable Activities for Emergency and Expedited Excreta Bioassay During 1992

\begin{tabular}{|c|c|c|}
\hline \multirow{2}{*}{ Analysis $^{(a)}$} & \multicolumn{2}{|c|}{$\begin{array}{c}\text { MDA } \\
\text { (per sample) }\end{array}$} \\
\hline & Urine & Feces \\
\hline \multicolumn{3}{|l|}{ Emergency Analyses ${ }^{(b)}$} \\
\hline Isotopic plutonium by alpha spectrometry & $0.5 \mathrm{dpm}$ & $9 \mathrm{dpm}$ \\
\hline Isotopic uranium by alpha spectrometry & $1.0 \mathrm{dpm}$ & $12 \mathrm{dpm}$ \\
\hline${ }^{241} \mathrm{Am}$ & $1.0 \mathrm{dpm}$ & $20 \mathrm{dpm}$ \\
\hline Total radiostrontium & $80 \mathrm{dpm}$ & $450 \mathrm{dpm}$ \\
\hline Elemental uranium & $\mu \mathrm{g}$ & $8 \mu \mathrm{g}$ \\
\hline Tritium & $\mathrm{dpm} / \mathrm{mL}$ & - \\
\hline \multicolumn{3}{|l|}{ Expedited Analyses $^{(c)}$} \\
\hline Isotopic plutonium by alpha spectrometry & $0.08 \mathrm{dpm}$ & $3 \mathrm{dpm}$ \\
\hline Isotopic uranium by alpha spectrometry & $0.12 \mathrm{dpm}$ & $4 \mathrm{dpm}$ \\
\hline${ }^{241} \mathrm{Am}$ & $0.08 \mathrm{dpm}$ & $6 \mathrm{dpm}$ \\
\hline Total radiostrontium & $50 \mathrm{dpm}$ & $150 \mathrm{dpm}$ \\
\hline Elemental uranium & $0.5 \mu \mathrm{g}$ & $5 \mu \mathrm{g}$ \\
\hline Tritium & $100 \mathrm{dpm} / \mathrm{mL}$ & - \\
\hline
\end{tabular}

(a) For the more critical analyses only. The list does not contain all the analyses covered in the contract.

(b) Verbal reporting time was generally within 8 hours after receipt of the sample; reporting times were even shorter for some analyses.

(c) Verbal reporting time was by 9:00 a.m. on the second business day after receipt of the sample.

\subsubsection{Excreta Bioassay Contract Status}

On October 22, 1991, International Technology Analytical Services (ITAS) was awarded a fiveyear contract with Battelle, Pacific Northwest Laboratories, to provide a full range of bioassay analytical services. The contract covers

- distribution and collection of bioassay sampling kits at workers' residences or other designated locations;

- sample handling and storage;

- analytical testing of samples;

- reporting of results; and

- disposal of sample residuals. 
The fifth operational year of the contract will end June 30,1996, after which the contract may be extended for three additional years.

\subsubsection{Excreta QC Oversight Program}

In fiscal year 1992, IDP submitted 281 samples with known amounts of various radionuclides (blanks and spikes) to ITAS to check the accuracy, precision, and detection levels of IDP urinalyses for tritium, ${ }^{90} \mathrm{Sr},{ }^{238} \mathrm{Pu},{ }^{239} \mathrm{Pu},{ }^{241} \mathrm{Am},{ }^{242} \mathrm{Cm},{ }^{244} \mathrm{Cm},{ }^{234} \mathrm{U},{ }^{235} \mathrm{U},{ }^{238} \mathrm{U}$, and natural uranium. The quality control (QC) samples submitted represented about $4 \%$ of the 6511 samples submitted. This percentage, which was about the same as in previous years, maintained the increase in absolute numbers established during the multilaboratory period between long-term contractors (June 1, 1990, through October 22, 1991).

Urine collected from nonexposed PNL employees was prepared as blank and spiked samples by PNL's Analytical Chemistry Laboratory (ACL) in the 325 Building, according to the directions given by the IDP. Most samples were submitted as double blind samples; that is, they were scheduled with and collected by ITAS as if they were personnel samples. Additional samples were prepared by Oak Ridge National Laboratory (ORNL) and submitted to ITAS as "open" audit, or single blind, samples (ITAS was aware that the samples were QC samples, but did not know the spike amounts). Analyses for tritium, ${ }^{90} \mathrm{Sr},{ }^{238} \mathrm{Pu},{ }^{239} \mathrm{Pu},{ }^{241} \mathrm{Am},{ }^{242} \mathrm{Cm},{ }^{244} \mathrm{Cm}$, ${ }^{234} \mathrm{U},{ }^{235} \mathrm{U},{ }^{238} \mathrm{U}$, and natural uranium were checked. Natural uranium was tested using two different procedures.

ITAS was also required to conduct their own QC program and submit the results of analyses to the IDP. The external audit sample program of Battelle, Pacific Northwest Laboratories, provided a check on ITAS's own internal QC programs. The results of the external audit program were generally the same as for ITAS's internal QC program. All analyses met or exceeded specifications in the SOW, except the ${ }^{241} \mathrm{Am}$ analytical procedure, which had an unacceptably high detection level. This may have been an artifact related to the small number of audit samples submitted. The IDP will continue tracking ${ }^{241} \mathrm{Am}$ and run the statistics again when sufficient samples have been analyzed.

At the request of the IDP, a new low-sensitivity plutonium procedure (IPUL) was developed by ITAS and tested to supplement the standard plutonium procedure. Results from the quality control samples submitted by the IDP to ITAS to test this procedure were considered unsatisfactory; the mean blank value was only slightly less than the mean value for samples spiked at the contractual detection level $(0.005 \mathrm{dpm})$. This procedure will not be used for the bioassay program until compliance with the contract performance specifications is demonstrated. 


\subsubsection{Program Change Records}

Small-scope changes to the practices or technical aspects of the IDP are documented by Program Change Records. Ultimately, these changes become incorporated into the Technical Basis for Internal Dosimetry at Hanford (Sula, Carbaugh, and Bihl 1991), the Hanford Internal Dosimetry Program Manual, ${ }^{(a)}$ or the Hanford Internal Dosimetry Procedures Manual. ${ }^{(b)}$ The Program Change Record identifies the change, its effective date, and the reasons for and impacts of the change. A copy of the record is placed in the Hanford Radiation Protection Historical Files. Program Change Records issued by the IDP in 1992 are shown in Table 2.4.

\subsubsection{Program Changes in Response to the DOE Radiological Control Manual}

DOE issued its Radiological Control Manual in June 1992. This manual prescribed detailed requirements for radiological safery and administration for DOE sites. The major impact on the IDP was a mandatory switch from calculating and reporting internal doses in annual increments to a 50-year committed dose assigned to the year of intake. Two major actions were taken in response to this manual:

- The IDP participated on a subcommittee of the Hanford Personnel Dosimetry Advisory Committee that provided detailed guidance on when workers should be placed on a bioassay program. This guidance was incorporated into Chapter 5 of HSRCM-1 (RL 1992).

- The IDP submitted to and received concurrence from the Hanford Personnel Dosimetry Advisory Committee for a series of programmatic changes that were to take effect on February 1,1993. Some of these changes include reporting committed effective and organ doses (annual doses will still be calculated but not reported), doing five-year reevaluations for intakes with committed doses above $20 \%$ of the applicable radiation protection standard, and calculating committed doses for workers with internal dose from employment prior to Hanford. The 10-mrem annual effective dose equivalent (AEDE) screening level for bioassay results was not changed pending release of additional guidance in the implementation guide on internal dosimetry.

(a) Internal manual, PNL-MA-552, Pacific Northwest Laboratory, Richland, Washington.

(b) Internal manual, PNL-MA-565, Rev 0, Pacific Northwest Laboratory, Richland, Washington. 
Table 2.4. Program Change Records for 1992

\begin{tabular}{|c|c|c|c|}
\hline PCR No. & $\begin{array}{l}\text { Effective } \\
\text { Date }\end{array}$ & Title & Affected Program Areas \\
\hline $92-001$ & $01-01-92$ & $\begin{array}{l}\text { Quarterly Soluble Uranium } \\
\text { Screening Levels }\end{array}$ & $\begin{array}{l}\text { Established screening level for workers } \\
\text { with very infrequent entries to UO3 } \\
\text { Plant. }\end{array}$ \\
\hline $92-002$ & $01-01-92$ & $\begin{array}{l}\text { Quarterly Insoluble Uranium } \\
\text { Supplemental Screening } \\
\text { Levels }\end{array}$ & $\begin{array}{l}\text { Established immediate assessment } \\
\text { action levels for chronically exposed } \\
\text { workers who might otherwise not be } \\
\text { assessed until calendar year-end. }\end{array}$ \\
\hline $92-003$ & $01-06-92$ & $\begin{array}{l}\text { Implementation of the } \\
\text { Policies Cited in the WBC } \\
\text { Program Statement of Work } \\
\text { (SOW) }\end{array}$ & $\begin{array}{l}\text { Adopted changes in operating policies } \\
\text { of Hanford In Vivo Measurement } \\
\text { Program, including change in chest } \\
\text { counting times from } 2000 \text {-s to } 1200-\mathrm{s} \text {, } \\
\text { adoption of ANSI N } 13.30 \text { based } \\
\text { statistics, and use of decision level }\left(\mathrm{L}_{\mathrm{c}}\right) \\
\text { instead of MDA to determine if results } \\
\text { are different from background. }\end{array}$ \\
\hline $92-004$ & $08-01-92$ & Tritium Screening Levels & $\begin{array}{l}\text { Provided additional } 10 \text {-mrem based } \\
\text { screening levels for special sampling } \\
\text { following single acute intakes. }\end{array}$ \\
\hline $92-005$ & $08-25-92$ & Recounted Chest Counts & $\begin{array}{l}\text { Added additional statement to } \\
\text { preliminary in vivo exam letters } \\
\text { explaining false-positive results. }\end{array}$ \\
\hline $92-006$ & $09-09-92$ & $\begin{array}{l}\text { Radon Daughters Technical } \\
\text { Basis for Internal Dosimetry }\end{array}$ & $\begin{array}{l}\text { Established method for calculating } \\
\text { committed effective dose equivalents } \\
\text { from reported Working Level Months } \\
\text { data. }\end{array}$ \\
\hline
\end{tabular}

\subsubsection{The Hanford Internal Dosimetry Procedures Manual}

In September the program issued the Hanford Internal Dosimetry Procedures Manual, ${ }^{\left({ }^{a}\right)}$ which provides day-to-day detailed procedures for work performed by the IDP staff. The manual includes procedures for use of the various computer programs used by the IDP, including ORE. Issuance of this document completed the original vision for documentation of the IDP, which provided for three major documents: the Technical Basis for Internal Dosimerry at Hanford, ${ }^{(b)}$

(a) Internal manual, PNL-MA-565, Rev. 0, Pacific Northwest Laboratory, Richland, Washington.

(b) First issued in 1989. 
the Hanford Internal Dosimetry Program Manual, (a) and the procedures manual. Work on the procedures manual was purposely postponed because of the short-term nature of the interim bioassay program from June 1990 through November 1991.

\subsection{MONITORING AND ASSESSMENT ACTIVITIES}

IDP excreta bioassay monitoring and internal dose assessment activities during 1992 are summarized in this section. The in vivo bioassay monitoring program and its associated statistics are discussed in Chapter 3.0, "Hanford In Vivo Measurement Program."

\subsubsection{Excreta Bioassay Monitoring Activities}

Sample requests can be categorized as standard or nonstandard. Standard requests are those generated by the Occupational Radiation Exposure system (ORE) database from a predetermined, routine schedule (for instance, a worker may be scheduled for an annual sample collected every April). These requests are downloaded from ORE and electronically transferred to the ITAS laboratory just before the start of each month. All other requests are considered nonstandard requests. Contractors make the nonstandard requests to the IDP manually. The IDP initiates the paperwork and then transfers the request to the Hanford Radiological Records Program. After loading the request into ORE, Radiological Records has the computer transfer the request to the laboratory. Nonstandard requests are a much more labor-intensive process. Figure 2.1 shows the monthly distribution of standard and nonstandard requests for 1992 . A total of 9876 samples were requested in 1992, up 6\% over the 1991 requests. The majority of the samples $(62 \%)$ were standard requests, with $38 \%$ being nonstandard. In contrast, the respective percentages in 1991 were $47 \%$ and $53 \%$. The data indicate a relatively constant sample request rate throughout the year of about 825 samples per month.

During the year, 7929 excreta bioassay measurements were successfully performed in support of Hanford activities, excluding cancellations, no-samples, samples without valid results, and audit samples. Of these, $98 \%$ were classified as routine (including measurements on visitors), and about $2 \%$ were due to special circumstances, such as response to unplanned potential intakes or follow-up analyses to high routine measurements.

The 1992 excreta results statistics are summarized in Table 2.5. The total number of samples continued the increasing trend of prior years, as depicted in Figure 2.2. Major increases occurred in the number of tritium and uranium analyses, and there were modest decreases in the number of strontium and transuranic (plutonium, americium, and curium) analyses. Overall, there was a $7.4 \%$ increase over 1991 in the total number of routine measurements.

(a) Internal manual, PNL-MA-552, Pacific Northwest Laboratory, Richland, Washington. 


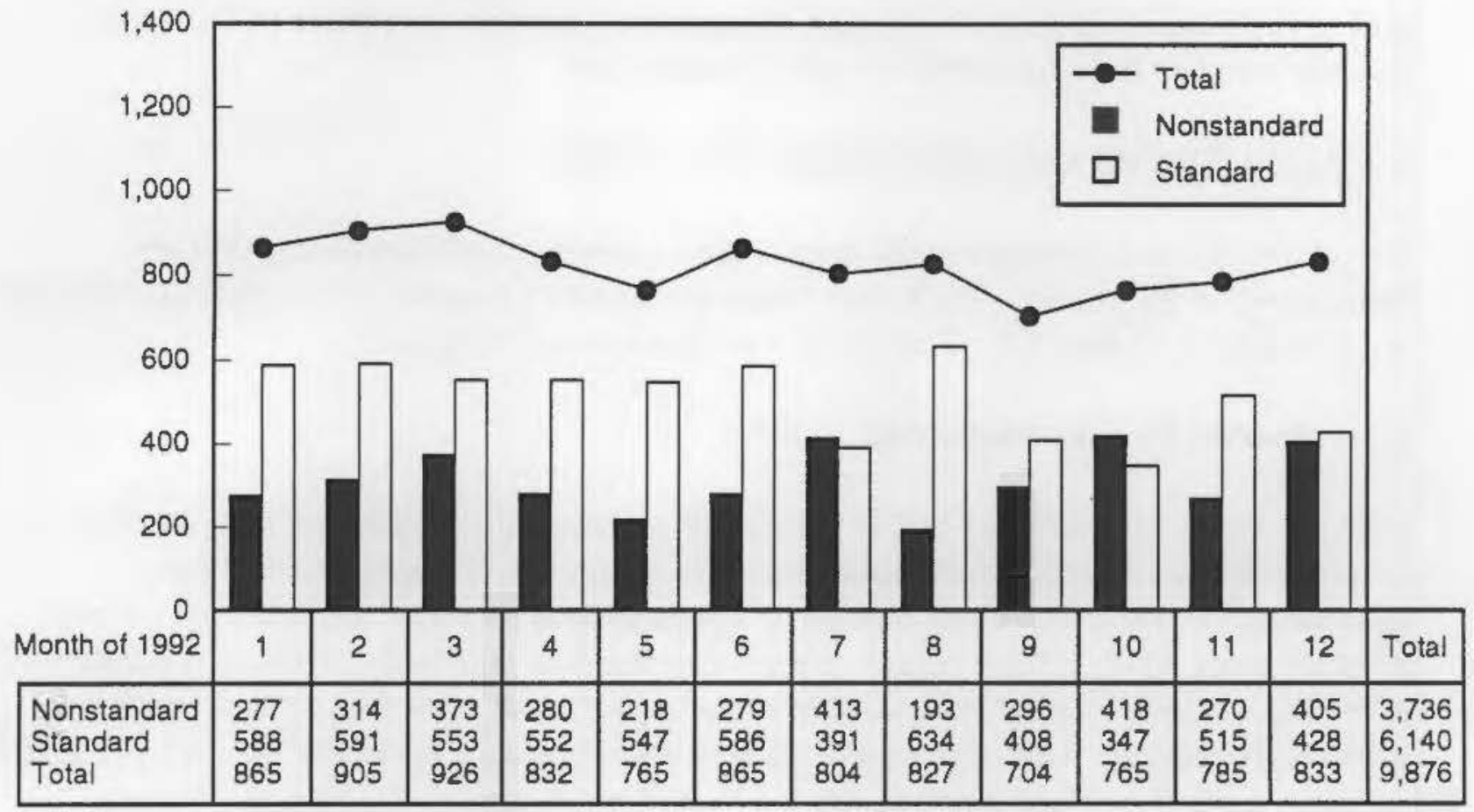

S9305057.1

Figure 2.1. Standard and Nonstandard Excreta Requests by Month

In addition, a total of 2761 excreta sample analysis requests were designated as no-result samples for 1992. Unsuccessful sample collections (their associated no-result code and percentage of the total no-results) were attributed to the following causes: kit not delivered (ND, 27\%), no sample received (NS, 15\%), lost container (LC, 34\%), insufficient sample volume (IS, 10\%), and lostin-lab (LL, $14 \%)$.

The unsuccessful-sample retrieval rate of $28 \%$ for 1992 was substantially higher than rates for the preceding years. This rate reflects a large number of samples for which requests were made but no sample kits were delivered by the contracted analytical support laboratory. This problem, which was associated with the startup of the new permanent analytical support laboratory, was identified early in the year. The ND code was initiated in summer 1992; no reason for the high number of undelivered kits in February and March was given. Corrective actions were implemented, and the rate appeared to decrease in later months. When adjusted for this factor, the no-results rate drops to $20 \%$ for 1992 . The adjusted 1992 no-results rate was still higher than that for earlier years (12\% for 1991 and $19 \%$ for 1990). 
Table 2.5. Worker Excreta Measurements Reported for 1992 Samples

\begin{tabular}{|c|c|c|c|c|c|}
\hline Type/Reason & DOE & KEH & PNL & WHC & TOTAL \\
\hline \multicolumn{6}{|l|}{${ }^{3} \mathrm{H}$-urine } \\
\hline Routine schedule ${ }^{(a)}$ & 4 & 545 & 682 & 117 & 1348 \\
\hline Special request ${ }^{(b)}$ & 0 & 0 & 0 & 0 & 0 \\
\hline \multicolumn{6}{|l|}{${ }^{90} \mathrm{Sr}$-urine } \\
\hline Routine schedule & 22 & 410 & 11 & 957 & 1400 \\
\hline Special request & 0 & 1 & 0 & 1 & 2 \\
\hline \multicolumn{6}{|l|}{ Uranium-urine } \\
\hline Routine schedule & 13 & 277 & 150 & 1684 & 2124 \\
\hline Special request & 0 & 3 & 2 & 14 & 19 \\
\hline \multicolumn{6}{|l|}{ Plutonium-urine } \\
\hline Routine schedule & 26 & 554 & 206 & 2146 & 2932 \\
\hline Special request & 0 & 2 & 9 & 41 & 52 \\
\hline \multicolumn{6}{|l|}{ Other TRU-urine } \\
\hline Routine schedule & 0 & 5 & 13 & 12 & 3013 \\
\hline Special request & 0 & 0 & 4 & 9 & \\
\hline \multicolumn{6}{|l|}{ Plutonium-fecal } \\
\hline Routine schedule & 0 & 0 & 1 & 0 & 1 \\
\hline Special request & 0 & 0 & 3 & 3 & 6 \\
\hline${ }^{241} \mathrm{Am}$-fecal & 0 & 0 & 0 & 2 & 2 \\
\hline Analyses Totals & 65 & 1797 & 1081 & 4986 & 7929 \\
\hline \multicolumn{6}{|l|}{ Recounts } \\
\hline Plutonium - urine & 0 & 6 & 10 & 57 & 73 \\
\hline${ }^{90} \mathrm{Sr}$ - urine & 0 & 0 & 0 & 0 & 0 \\
\hline${ }^{3} \mathrm{H}$ - urine & 0 & 1 & 3 & 0 & 4 \\
\hline Uranium - urine & 0 & 3 & 15 & 7 & 25 \\
\hline
\end{tabular}

(a) Routine measurements include those with reason codes of baseline, beginning work, new hire, routine, ending work, termination, contractor request, and evaluator request.

(b) Special measurements include those with reason codes of incident, investigate high result, and follow-up. 


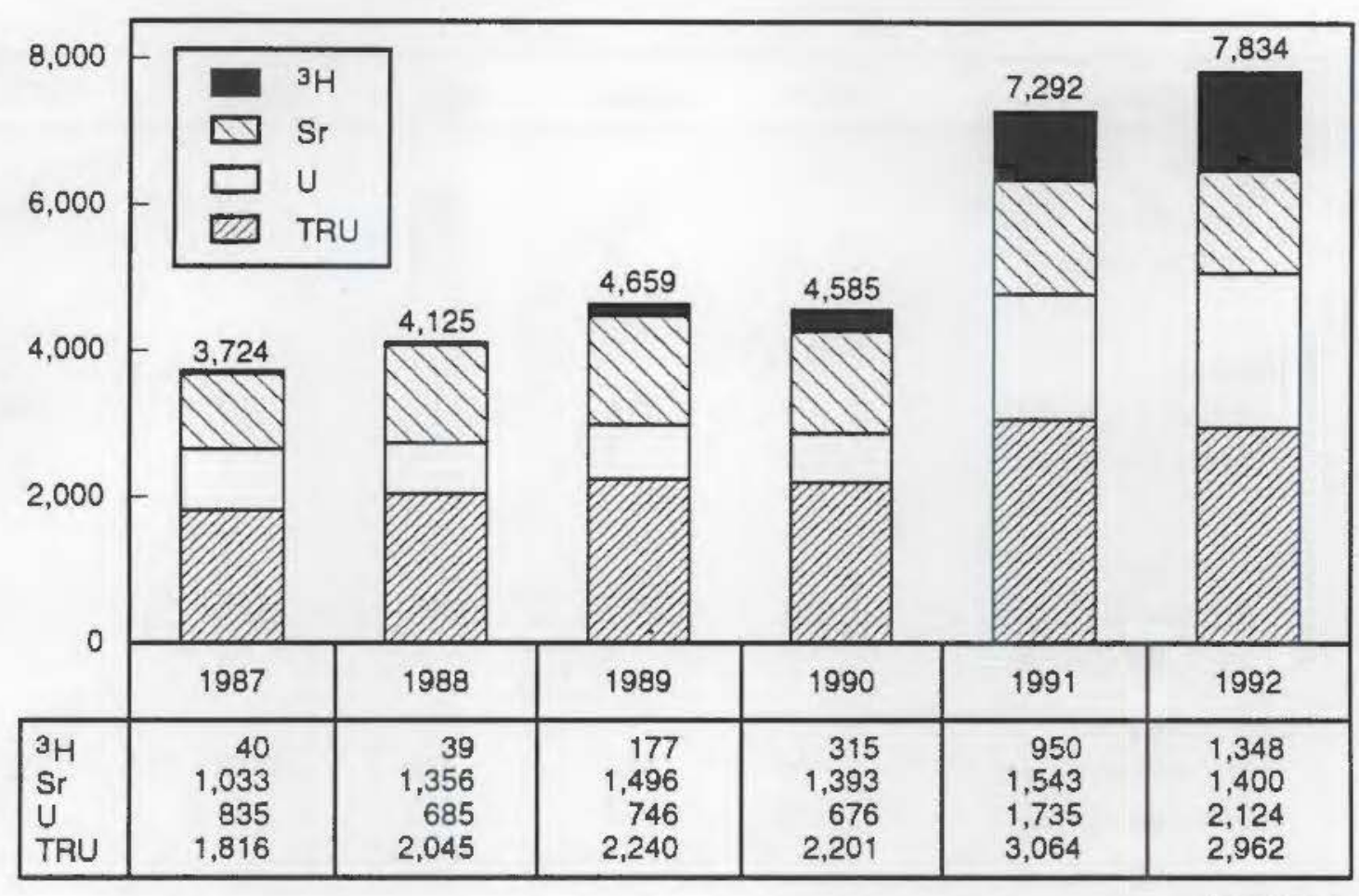

$\$ 9305057.2$

Figure 2.2. Routine Urine Measurements Made from 1986 Through 1991

\subsubsection{Internal Dose Assessment Activities}

Investigations of possible internal exposure to radionuclides are performed following an indication from a routinely scheduled bioassay measurement, or for a potential exposure incident identified in the workplace. Potential exposure incidents are identified by workplace indicators such as air sampling, contamination surveys, nasal smears, or smears from potentially contaminated wounds. Special-request bioassay measurements are also performed at the request of workers through the contractor dosimetry group.

During the year, 12 potential internal exposure incidents involving 21 workers were identified through workplace monitoring. Of these workers, no confirmation of intake was determined for 17 workers, and intakes were confirmed for 4 workers. The highest calculated dose for the 4 workers was only 3 -mrem committed effective dose equivalent (CEDE). The radionuclides and groups involved included ${ }^{137} \mathrm{Cs}$ and $/$ or ${ }^{90} \mathrm{Sr}$ ( 5 incidents with 10 workers), TRU (4 incidents with 5 workers), and $\mathrm{U}$ ( 3 incidents with 6 workers). Table 2.6 shows the incident breakdown by contractor, area, and facility. Trends for the last five years are included in Table 2.7. 
Table 2.6. Summary of Potential Exposure Incidents During 1992

\begin{tabular}{|c|c|c|c|c|c|c|}
\hline \multicolumn{2}{|c|}{ Facility } & \multirow[b]{2}{*}{ Custodian } & \multirow{2}{*}{$\begin{array}{c}\text { Number of } \\
\text { Incidents }\end{array}$} & \multirow{2}{*}{$\begin{array}{c}\text { Number of } \\
\text { Workers }\end{array}$} & \multirow{2}{*}{$\begin{array}{c}\text { Worker } \\
\text { Contractor }\end{array}$} & \multirow[b]{2}{*}{$\begin{array}{r}\text { Principal } \\
\text { Nuclide }\end{array}$} \\
\hline Area & ID & & & & & \\
\hline $100 \mathrm{~A}$ & $105 \mathrm{KE}$ & WHC & 1 & 4 & WHC & ${ }^{137} \mathrm{Cs}$ \\
\hline \multirow[t]{2}{*}{$200 E$} & Purex & WHC & 1 & 1 & WHC & ${ }^{239} \mathrm{Pu}$ \\
\hline & B-Plant & WHC & 1 & 3 & WHC & ${ }^{137} \mathrm{Cs}$ \\
\hline \multirow[t]{3}{*}{$200 W$} & $224 \mathrm{U}$ & WHC & 3 & 6 & WHC & U-nat \\
\hline & $222 \mathrm{~S}$ & WHC & 1 & 2 & $\mathrm{KEH}$ & ${ }^{241} \mathrm{Am}$ \\
\hline & 101SY & WHC & 1 & 1 & KEH & ${ }^{137} \mathrm{Cs}$ \\
\hline \multirow[t]{4}{*}{300} & 325 & PNL & 1 & 1 & $\mathrm{KEH}$ & ${ }^{239} \mathrm{Pu}$ \\
\hline & & & 1 & 1 & $\mathrm{KEH}$ & ${ }^{137} \mathrm{Cs}$ \\
\hline & & & 1 & 1 & PNL & ${ }^{239} \mathrm{Pu}$ \\
\hline & 327 & PNL & 1 & 1 & KEH & ${ }^{137} \mathrm{Cs}$ \\
\hline \multirow[t]{2}{*}{400} & & & 0 & 0 & & \\
\hline & & & Total 12 & 21 & & \\
\hline
\end{tabular}

Initial evaluations were issued for the following radionuclides or groups: TRU ( 49 cases), ${ }^{137} \mathrm{Cs}$ and/or ${ }^{90} \mathrm{Sr}$ (12 cases), uranium and/or thorium-234 (117 cases), tritium (4 cases), and other radionuclides ( 4 cases). Of these, 145 cases received no occupational internal dose (i.e., no confirmation of any occupational intake), 10 cases received CEDEs less than $100 \mathrm{mrem}$, and 5 cases received CEDEs greater than 100 mrem. Table 2.8 shows internal dose evaluations for 1992 resulting from high routine-bioassay results (i.e., those not associated with known incidents or known potential-chronic-exposure situations, and exceeding the criteria for investigation). 
Table 2.7. Comparison of Internal Exposure Incidents and Internal Exposure Dose Assessments, 1988-1992

\begin{tabular}{|c|c|c|c|c|c|}
\hline & 1988 & 1989 & 1990 & 1991 & 1992 \\
\hline Incidents, Total & 12 & 22 & 14 & 15 & 12 \\
\hline Workers involved & 25 & 33 & 30 & 30 & 21 \\
\hline Evaluations, Total & 80 & 291 & 228 & 130 & 190 \\
\hline Reevaluations & 8 & 7 & 5 & 1 & $4^{(a)}$ \\
\hline New Cases & 72 & 284 & 223 & 129 & 186 \\
\hline Incidents & 26 & 33 & 30 & 30 & 21 \\
\hline Special requests & 8 & 3 & 5 & 0 & 0 \\
\hline High routines & 38 & 51 & 93 & 69 & 141 \\
\hline Chronic exposures ${ }^{(b)}$ & - & 197 & 95 & 30 & 4 \\
\hline Pre-Hanford exposure & - & - & - & - & 20 \\
\hline No Dose $e^{(c)}$ & 22 & 77 & 104 & 85 & 160 \\
\hline
\end{tabular}

(a) Four additional reevaluations were assigned in 1992 but were not completed at the time of this compilation.

(b) The criteria for deciding which chromically exposed workers were to be evaluated changed considerably from 1987 to 1991 , so the yearly numbers are not very comparable.

(c) From 1986 to 1988 , the cutoff for dose assessment was $1 \%$ of the radiation protection standard or maximum permissible body burden. Beginning in 1989, dose from any confirmed intake was recorded. 
Table 2.8. Summary of Confirmed Intake Cases Identified Through the Routine Bioassay Program During 1992

\begin{tabular}{|c|c|c|c|c|c|c|}
\hline \multicolumn{2}{|c|}{ Facility } & \multirow[b]{2}{*}{ Custodian } & \multirow[b]{2}{*}{ Type ${ }^{(a)}$} & \multirow[b]{2}{*}{$\begin{array}{c}\text { Number of } \\
\text { Workers }\end{array}$} & \multirow[b]{2}{*}{$\begin{array}{l}\text { Worker } \\
\text { Contractor }\end{array}$} & \multirow[b]{2}{*}{$\begin{array}{c}\text { Principal } \\
\text { Nuclide }\end{array}$} \\
\hline Area & ID & & & & & \\
\hline $200 \mathrm{E}$ & $209 \mathrm{E}$ & PNL & A & 1 & PNL & ${ }^{239} \mathrm{Pu}$ \\
\hline $200 \mathrm{~W}$ & $224-U$ & WHC & A & 3 & WHC & U-nat \\
\hline & $234-5 Z$ & WHC & A & 3 & WHC & ${ }^{239} \mathrm{Pu}$ \\
\hline \multirow[t]{7}{*}{$300 \mathrm{~A}$} & $333-W$ & WHC & C & 1 & WHC & U-nat \\
\hline & Unknown $^{(b)}$ & & A & 1 & WHC & U-nat \\
\hline & Non-Hanford & & $A^{(c)}$ & 1 & WHC & ${ }^{137} \mathrm{Cs}$ \\
\hline & & & & 1 & WHC & ${ }^{60} \mathrm{Cs}$ \\
\hline & & & & 1 & WHC & ${ }^{3} \mathrm{H}$ \\
\hline & & & $A^{(d)}$ & 3 & PNL & ${ }^{3} \mathrm{H}$ \\
\hline & & & & Total 15 & & \\
\hline
\end{tabular}

(a) Acute (A) or chronic (C) intake scenarios.

(b) Worker was assigned to 222-T, but no specific facility was identified as the likely place of intake.

(c) Occupational intake prior to Hanford employment.

(d) Occupational intakes at non-Hanford facility, but occurring while employed by Hanford contractor.

Workers who were identified as having potential chronic exposures to uranium or tritium were reviewed at the year end if any single sample result exceeded the monthly screening level. Dose assessments were issued only for those workers who then exceeded the chronic intake investigation level, defined as that result which could have indicated a potential first-year effective dose equivalent greater than $10 \mathrm{mrem}$, based on conservative assumptions. None of the chronic intake evaluations resulted in CEDEs in excess of $100 \mathrm{mrem}$; one chronic tritium worker was assessed a CEDE of $11 \mathrm{mrem}$, and two chronic insoluble uranium workers were assessed CEDEs below 100 mrem. Data indicated that no soluble-uranium worker on a chronic exposure monitoring program would have exceeded a CEDE of $2 \mathrm{mrem}$, based on chronic intake during 1992.

The internal dose status of the Hanford work force at the end of 1992 is summarized in Table 2.9. Past exposures that are contributing current doses to active workers are included in the lower section of the table. Overall, the number of Hanford workers receiving internal doses during 1992 has decreased by $11 \%$ since 1991 . Of the new evaluations listed, all but 8 cases resulted in CEDEs of less than $100 \mathrm{mrem}$, which were assigned to the year of intake, in accordance with current Hanford practices for recording low doses. 
Table 2.9. Internal Dose Status of the Hanford Work Force at 1992 Year End

\begin{tabular}{llllll}
\hline & \multicolumn{5}{c}{ Number of Workers $^{(\mathrm{a})}$} \\
\cline { 2 - 6 }${\text { Dose }(\mathrm{mrem})^{\text {(b) }}}$ & DOE & KEH & PNL & WHC & Total \\
\hline AEDE (any year by 1992 evaluations) & & & & & \\
$<100$ & 0 & 2 & $6(3)$ & $11(1)$ & 19 \\
$100-<500$ & 0 & 0 & 1 & 2 & 3 \\
$500-<2000$ & 0 & 0 & 0 & $2(2)$ & 2 \\
$2000-<5000$ & 0 & $1(1)$ & 0 & $1(1)$ & 2 \\
$>5000$ & 0 & 0 & 0 & 0 & 0 \\
\hline
\end{tabular}

CEDE (any year by 1992 evaluations)

\begin{tabular}{llllll}
$<100$ & 0 & 2 & 6 & $10(1)$ & 18 \\
$100-<5000$ & 0 & 0 & 0 & 0 & \\
$500-<2000$ & 0 & 0 & 0 & $4(1)$ & 4 \\
$2000-<5000$ & 0 & $1(1)$ & 1 & $1(1)$ & 3 \\
$\geq 5000$ & 0 & 0 & 0 & $1(1)$ & 1 \\
\hline
\end{tabular}

1992 AEDE by 1992 evaluations

\begin{tabular}{llllll}
$<100$ & 0 & 2 & $6(3)$ & $10(1)$ & 18 \\
$100-<500$ & 0 & 0 & 1 & 2 & 3 \\
$500-<2000$ & 0 & 0 & 0 & $1(1)$ & 1 \\
$2000-<5000$ & 0 & 0 & 0 & 0 & 0 \\
$>5000$ & 0 & 0 & 0 & 0 & 0 \\
\hline
\end{tabular}

1992 AEDE by pre-1992 evaluations

$$
\begin{aligned}
& <100 \\
& 100-<500 \\
& 500-<2000 \\
& 2000-<5000 \\
& \geq 5000
\end{aligned}
$$

$1(1) \quad 1 \quad 15(2) \quad 24(1) \quad 41$

$\begin{array}{lllll}0 & 1 & 10 & 19(2) & 30\end{array}$

$\begin{array}{lllll}0 & 0 & 4 & 5 & 9\end{array}$

$1(1) \quad 0 \quad 0 \quad 3 \quad 4$

Total 1992 AEDE by all evaluations

$2 \quad 4 \quad 36$

(a) Numbers in parentheses refer to assessed doses due to offsite exposures.

(b) Annual effective dose equivalent (AEDE) or committed effective dose equivalent (CEDE) newly assessed for any year by 1992 evaluations. If the intake occurred in 1992 and the CEDE was less than 100 mrem, the total CEDE was assigned to 1992, and is shown in both the AEDE and CEDE entries. 
With the issuance of the DOE Radiological Control Manual, 1992 marked a transition in the reporting and recording of internal doses. This manual and the associated Hanford Site Radiological Control Manual, HSRCM-1 (RL 1992), mandated the use of CEDE assigned to the year of intake for the purpose of recording and reporting internal doses. This mandate was in sharp contrast to DOE 5480.11 (1990), which required the use of annually received doses (i.e., the AEDE). Transition from the use of AEDE to CEDE was not scheduled to begin until calendar year 1993; thus, the internal dose status of the work force shown in Table 2.9 is based on the AEDE.

\subsection{SUPPORTING STUDIES}

As a contingency for the potential loss of emergency bioassay analytical capabilities at PNL's long-term analytical contractor, the IDP maintains a work agreement with the PNL Analytical Chemistry Laboratory (ACL) for maintenance of emergency bioassay capabilities to rapidly analyze urine samples for plutonium and radiostrontium. ACL maintains a staff of three analysts trained on emergency plutonium and radiostrontium procedures, and participates in two drills per year on each emergency procedure. Participation in a drill consists of receipt, analysis, and verbal and written reporting of analytical results by ACL for one to three samples each for plutonium and radiostrontium. ACL met all performance expectations for the drills run in March and July of 1992 .

The IDP participated in a DOE-wide intercomparison exercise using the same data as a European study (Gibson et al. 1992). Four intercomparison cases were assessed using Hanford methods; one case involving ${ }^{137} \mathrm{Cs}$ and ${ }^{90} \mathrm{Sr}$, and three cases involving plutonium. Results of the intercomparison were not available at year end.

A second intercomparison, less formal but equally valid, occurred when the Savannah River Site requested independent evaluations of a $1991{ }^{238} \mathrm{Pu}$ intake. Evaluations were performed by Hanford, the Inhalation Toxicology Research Institute (ITRI), Lowell University, and Westinghouse Savannah River Company. The results, which were reported in a Westinghouse Savannah River Company report (La Bone et al. 1992), are summarized in Table 2.10. The four participants used considerably different methods to evaluate the case. The estimated CEDE ranged from 8 rem to 22 rem, with Hanford's estimate being exactly in the middle. 
Table 2.10. Intercomparison of ${ }^{238} \mathrm{Pu}$ Inhalation Dose Assessment

\begin{tabular}{|c|c|c|c|c|}
\hline \multirow[b]{2}{*}{ Factor } & \multicolumn{4}{|c|}{ Location $^{(a)}$} \\
\hline & $\begin{array}{l}\text { Savannah } \\
\text { River }\end{array}$ & Hanford & ITRI & $\begin{array}{l}\text { Lowell } \\
\text { University }\end{array}$ \\
\hline CEDE & $15.2 \mathrm{rem}$ & $15 \mathrm{rem}$ & $8.0 \mathrm{rem}$ & 22 rem \\
\hline $\begin{array}{l}\text { Method of } \\
\text { Assessment }\end{array}$ & Intake & $\begin{array}{l}\text { Uptake and } \\
\text { Material } \\
\text { Balance }\end{array}$ & Uptake & Intake \\
\hline Computer Code & INDOS & $\begin{array}{l}\text { PUCALC, } \\
\text { GENMOD, } \\
\text { Hand calc. }\end{array}$ & Not specified & INDOS \\
\hline Intake \& $\mathrm{AMAD}$ & $\begin{array}{l}330 \mathrm{~Bq} \\
0.35 \mu \mathrm{m}\end{array}$ & N/A & N/A & $\begin{array}{l}450 \mathrm{~Bq} \\
0.27 \mu \mathrm{m}\end{array}$ \\
\hline Uptake & N/A & $4.5 \mathrm{nCi}$ & $2.5 \mathrm{nCi}$ & N/A \\
\hline Initial Lung Deposit & N/A & $5.0 \mathrm{nCi}$ & $3.8 \mathrm{nCi}$ & N/A \\
\hline Lung Model & Class D & $\begin{array}{l}\text { Modified } \\
\text { Class D }\end{array}$ & $\begin{array}{l}\text { Modified } \\
\text { Class D }\end{array}$ & Class D \\
\hline $\begin{array}{l}\text { Urine Excretion } \\
\text { Model }\end{array}$ & Jones & Jones & $\begin{array}{l}\text { Mewhinney and } \\
\text { Diehl/Hickman }\end{array}$ & Jones \\
\hline $\begin{array}{l}\text { Systemic Retention } \\
\text { Models }\end{array}$ & $\begin{array}{l}\text { ICRP-30, } \\
\text { Part } 4\end{array}$ & ICRP-48 & ICRP-30, Part 1 & ICRP-30, Part 4 \\
\hline
\end{tabular}

(a) N/A $=$ Not applicable.

\subsection{PROGRAM-RELATED PROFESSIONAL ACTIVITIES}

IDP staff presentations and professional memberships during 1992 are listed in this section.

\subsubsection{Presentations}

Carbaugh, E. H. 1992. "Internal Doses-Are You Committed, Phobic, or Just Plain Confused?" Presented to the Columbia Chapter of the Health Physics Society, September 22, 1992, Richland, Washington.

Carbaugh, E. H., J. G. Bruce, and H. P. Spitz. 1992. "Attention Grabbing Visual Aids for Health Physics Presentations." Both poster and oral presentations were made at the Health Physics Society Annual Meeting, June 21-25, 1992, Columbus, Ohio. PNL-SA-20382, Pacific Northwest Laboratory, Richland, Washington. 
MacLellan, J. A., and K. M. McFadden. 1992. "Urine Sample Collection Protocols for Bioassay Samples." Presented at the 38th Annual Conference on Bioassay, Environmental, and Analytical Radiochemistry, November 2-5, 1992, Santa Fe, New Mexico.

\subsubsection{Professional Memberships}

MacLellan, J. A. Member of the ANSI Standard Committee for ANSI N13.30, Performance Criteria Against Which Radiobioassay Laboratories Will Be Tested. 



\subsection{HANFORD IN VIVO MEASUREMENT PROGRAM}

The Hanford In Vivo Measurement Program, which assists in detecting the deposition of radioactive materials in Hanford employees, has been an integral part of personnel dosimetry at Hanford since 1959. Program requirements are outlined in the Hanford Site Services Handbook. ${ }^{(a)}$ The In Vivo Measurement Program provides for the management, operation, and maintenance of the in vivo counting facilities and equipment located in the 747-A Building, the 747-A Trailer, a mobile in vivo counting facility, and the Emergency Decontamination Facility (EDF). The facilities are collectively known as the In Vivo Radioassay and Research Facility (IVRRF). The routinely used measurement facilities, located in the 747-A Building, include the Preview Counter (used for standup-screening, whole-body measurements); the Iron Room and Stainless Steel Room (each containing lung counting systems); and the Palmer Room (containing the coaxial germanium detector system). Operating hours are from 7:00 a.m. to 4:30 p.m. on weekdays. For special requests, additional hours can be scheduled to cover off-shift or after-work counts. The facilities and equipment are also available on an on-call basis during off-hours.

Data and results of measurements are transmitted to the Occupational Radiation Exposure (ORE) database for permanent record. Daily operational and functional checks are performed on all routinely used counting systems, which are also periodically calibrated to ensure accuracy in personnel measurements. The staff participate in intercomparison programs to further improve the accuracy of operations. The activities of this program, including special studies and development work performed during 1992, are described in this chapter.

\subsection{THE ROUTINE PROGRAM}

Activities in the routine program included making in vivo measurements and preparing for DOE accreditation.

\subsubsection{Routine In Vivo Measurements}

Several types of routine in vivo measurements are made on personnel at the Hanford Site. The type of measurement is determined by the type of radioactivity and/or location of a potential intake. Generally, if an employee does not work with uranium or transuranic (TRU) radionuclides, a whole-body count (WBC) is performed on the preview standup counter to detect the higher-energy gamma rays emitted by fission products or activation products. If the work involves TRU radionuclides or insoluble uranium isotopes, both lung and whole-body counts are completed. If radioactivity is detected by either of these measurements, several other types of counts may be done to identify and quantify the activity in the body.

(a) U.S. Department of Energy Richland Field Office (RL), 1993, RL 1400.1A, Richland, Washington (available online in HanInfo). 
All the routine counting systems are interfaced to the multichannel analyzers (MCAs) resident on a Digital Equipment Corporation (DEC) Model 3100 workstation. The workstation is interfaced to the Hewlett Packard (HP) 9000 computer. Codes were written for this workstation to back up the routine calculation codes on the HP 9000. Verification and validation of the codes for all systems have been completed. To date, no downtime related to failures of the MCAs has been experienced. (A second workstation was added and tied into the database to increase the reliability of routine counting tasks.)

Surveillances of the In Vivo Measurement Program were conducted by Westinghouse Hanford Company (WHC), PNL Facilities Maintenance, and the RL this year. Corrective actions were completed for all findings from the surveillances. The Program Statement of Work (SOW) ${ }^{(a)}$ was also completed this year. The SOW documents the operating policies for the program, including a new statistical approach based on the concepts presented in the draft ANSI standard N13.30, "Performance Criteria for Radiobioassay." The implementation of this SOW will begin after approvals have been granted from PNL and RL.

\subsubsection{Remote Counter}

The trailer housing the remotely operated in vivo counter was located in the 200 East Area and put into routine operation as a screening counter similar to the standup counter in the 747A Building. A total of 124 standup, whole-body counts were made from the remote location during 1992. This was the first full year of operation of the remote counter; increases in the through-put are expected in the future. Technicians in 747A remotely control the operation of the counting system from an IBM Model 25 with an MCA board. A second Model 25 in the trailer is connected via a modem. During remote measurements, continuous audible and visual communications are maintained with the subjects in the trailer. Visual images are transmitted to $747 \mathrm{~A}$ via a Photophone system, while a dedicated phone line between the trailer and 747 A provides audible communications. WHC personnel are trained to assist in the setup for the performance tests conducted before the system is used. This eliminates the need for IVRRF staff to travel to and from the counter for routine operations.

\subsubsection{Number of Measurements Performed}

The number and types of measurements made on personnel during 1992 are listed in Table 3.1. A total of 15,417 measurements were made for the $\mathrm{RL}$ and the Hanford contractors, representing a $19 \%$ increase over the number performed in 1991. These measurements were recorded in the ORE database. Figure 3.1 depicts the in vivo measurements made at the IVRRF (formerly known as the Whole Body Counting Facility) during the past five years. Lung counts for 1992 totaled 3164, a $24 \%$ increase from 1991.

(a) Lynch, T. P., J. A. MacLellan, and D. E. Bihl. 1992. "In Vivo Bioassay Statement of Work." PNL-7011, Pacific Northwest Laboratory, Richland, Washington 
Table 3.1. In Vivo Measurements Performed During 1992 and Recorded in the ORE Database

\begin{tabular}{lrrrrrrr}
\hline Type/Reasons & BCSR & DOE & HEHF & KEH & PNL & WHC & Total \\
\hline Whole-Body Count & & & & & & & \\
Routine schedule & 167 & 222 & 30 & 1,458 & 1,598 & 7,501 & 1,0976 \\
Special request & 26 & 32 & 6 & 15 & 36 & 446 & 561 \\
Visitors & 0 & 435 & 0 & 9 & 16 & 200 & 660 \\
\cline { 2 - 8 } TOTAL & 193 & 689 & 36 & 1,482 & 1,650 & 8,147 & 12,197 \\
\hline Chest Count & & & & & & & \\
& & & & & & & \\
Routine schedule & 30 & 6 & 1 & 642 & 377 & 1,841 & 2,897 \\
Special request & 13 & 2 & 2 & 6 & 13 & 228 & 264 \\
Visitors & 0 & 1 & 0 & 0 & 1 & 1 & 3 \\
TOTAL & 43 & 9 & 3 & 648 & 391 & 2,070 & 3,164 \\
\hline Other & & & & & & & \\
& & & & & & & \\
Head & 0 & 0 & 0 & 0 & 10 & 24 & 34 \\
Hand/wound & 0 & 0 & 0 & 5 & 2 & 5 & 12 \\
Thyroid & 0 & 0 & 0 & 0 & 2 & 0 & 2 \\
Other & 0 & 0 & 0 & 0 & 0 & 8 & 8 \\
TOTAL & 0 & 0 & 0 & 5 & 14 & 37 & 56 \\
\hline GRAND TOTAL & $\mathbf{2 3 6}$ & $\mathbf{6 9 8}$ & $\mathbf{3 9}$ & $\mathbf{2 , 1 3 5}$ & $\mathbf{2 , 0 5 5}$ & $\mathbf{1 0 , 2 5 4}$ & $\mathbf{1 5 , 4 1 7}$ \\
\hline
\end{tabular}




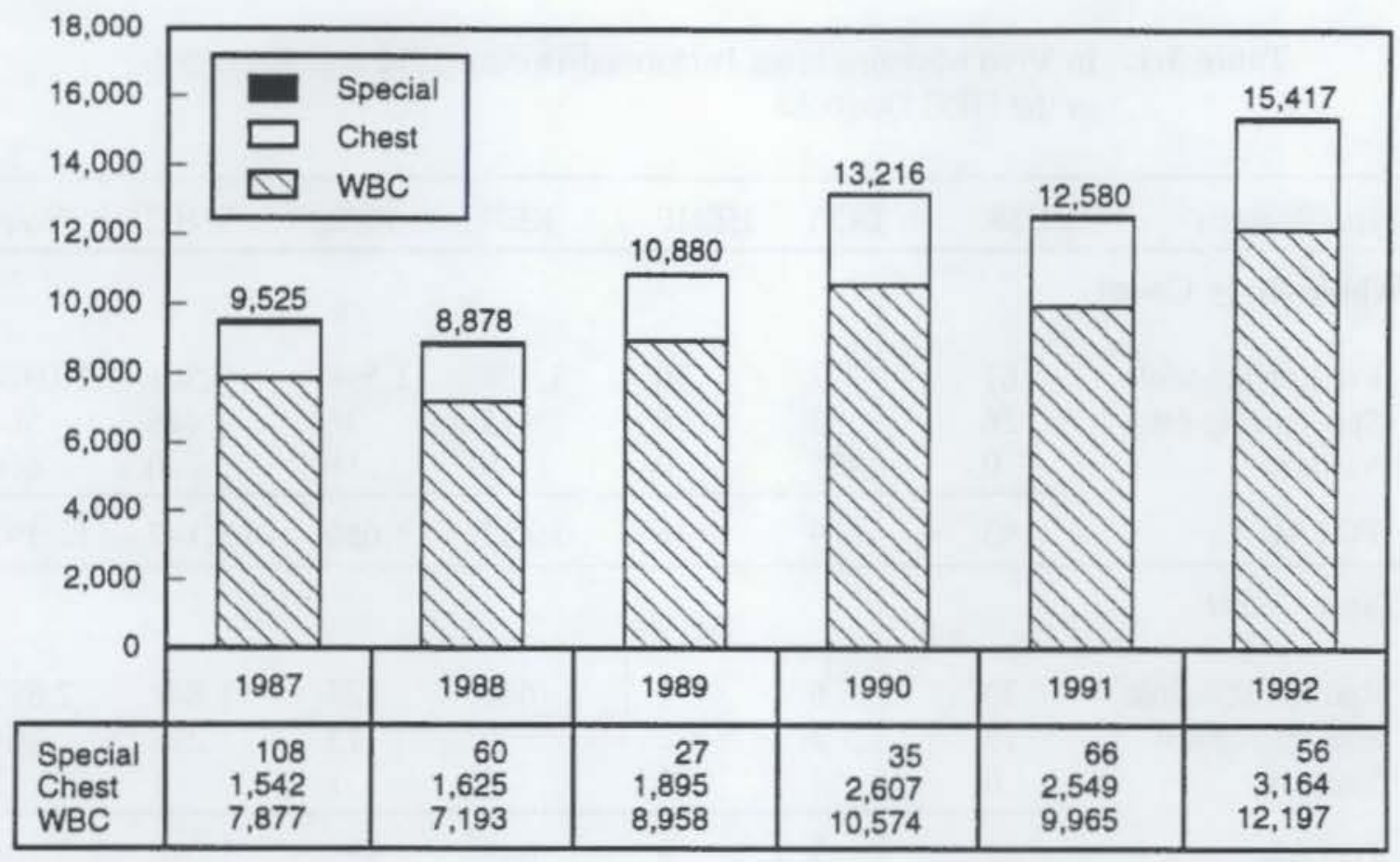

S9305057.3

Figure 3.1. In Vivo Measurements Made at the IVRRF from 1987 Through 1992

\subsubsection{Preparation for DOELAP Accreditation}

Preparation for meeting requirements of the DOE Laboratory Accreditation Program (DOELAP) began in 1991 and continued in 1992. A preliminary review of the IVRRF program was completed internally, and findings on the changes needed to meet the requirements of draft ANSI N13.30 were consolidated. A contract was written for several DOE-contractor bioassay scientists to visit PNL for a detailed evaluation and audit of the routine counting program. Dr. Richard Toohey from Argonne National Laboratory was chosen to lead the in vivo measurements evaluation.

A quality assurance plan was written as the basis for evaluating the program for DOELAP accreditation. The IVRRF quality assurance plan was developed to assist in satisfactory accreditation for the program under the upcoming DOELAP testing program for bioassay laboratories.

\subsection{ADDITIONS OR CHANGES TO EQUIPMENT AND FACILITIES}

In 1992, several additions and changes were made to equipment, facilities, and procedures in the In Vivo Measurement Program. These are described in the following subsections. 


\subsubsection{New Algorithms for IVRRF $L_{c}$ and Measurements}

A new set of algorithms, based on the statistical approach in the Statement of Work, was introduced into the computer programs that determine decision levels and activity determinations for all the measurement systems at the IVRRF. The decision level $\left(\mathrm{L}_{\mathrm{c}}\right)$ equation for the standup preview counter is

$$
\mathbf{L}_{\mathrm{c}}=\mathbf{K}_{\alpha} \sqrt{\mathbf{C}_{\mathbf{b}}\left(\mathbf{R}+\mathbf{R}^{2}\right)}+\left(\Delta_{B} C_{b} R\right)
$$

where $\mathrm{K}_{\alpha}=2.61$, corresponding to a $(1-2 \alpha)$ confidence interval, where $\alpha=0.0047$;

$\mathrm{C}_{\mathrm{b}}=$ counts in the background of the measured subject;

$\mathrm{R}=$ ratio of counts in the peak region to counts in the background region; and

$\Delta_{\mathrm{B}}=$ systematic error in background baseline determination, calculated from comparisons of two estimates of the propagated error in the net counts in the peak region of interest (ROI).

The $\mathrm{L}_{\mathrm{c}}$ equation for the IVRRF coaxial germanium array and the planar germanium chest counter array is

$$
L_{c}=K_{\alpha} \sqrt{C_{b}\left[\left(\frac{n_{1}}{n_{2}}\right]+\left(\frac{n_{1}}{n_{2}}\right)^{2}\right]+F T+\Delta_{B} B}
$$

where $\mathrm{K}_{\alpha}=2.783$ for the coaxial germanium array, corresponding to a (1-2 $\left.\alpha\right)$ confidence interval, where $\alpha=0.0027$; and $\mathrm{K}_{\alpha}=2.122$ for the germaniun chest counter array, where $\alpha=0.01695$;

$\mathrm{C}_{\mathrm{b}}=$ counts in the background of the measured subject;

$\mathrm{n}_{\mathrm{i}}=$ the number of channels used in determining the background and peak ROI regions $\left(n_{1}=\right.$ peak ROI channels, $n_{2}=$ background ROI channels);

$\mathrm{F}=$ the baseline correction factor, defined as the correction applied to the peak net counts in the region due to environmental and fallout radionuclides (this factor is individually calculated and verified for each peak ROI);

$T=$ count time in seconds;

$\Delta_{\mathrm{B}}=$ systematic error in background baseline determination, calculated from comparisons of two estimates of the propagated error in the net counts in the peak ROI; and

$B=$ baseline $=C_{b}\left(\frac{B_{p}}{B_{b}}\right)$ 
where $\mathrm{C}_{\mathrm{b}}=$ counts in background ROI of the measurement subject;

$\mathrm{B}_{\mathrm{p}}=$ average counts in peak ROI for "cold" subjects; and

$\mathrm{B}_{\mathrm{b}}=$ average counts in background ROI for "cold" subjects.

These new algorithms were implemented based on recommendations in draft ANSI N13.30. For routine measurements of both the lung and whole body, the false positive rate for the $\mathrm{Lc}$ was changed to $5 \%$ total false positives per measurement. For nonroutine measurements such as wound counts, the false positive rate was changed to $5 \%$ per radionuclide, regardless of the number of radionuclides being measured in a count. These changes resulted in increased false positive results of Hanford workers as compared to the minimum detectable activity (MDA) basis for whole-body counting used previously at the IVRRF and Hanford. To reduce the total number of false positives, the counting time was reduced to 20 minutes for chest counts and 50 minutes for recounts of false positive results.

The new algorithms were implemented on the routine counting systems at the IVRRF in 1992. Validation of these changes were completed by analyzing past counting results, as well as by using multiple calibration-phantom measurement data. A quarterly check of the false-positive rate for the routine measurement systems is maintained.

\subsubsection{New Image Analysis Procedure}

A new image analysis procedure for ultrasound measurements of chest walls for lung counting was developed and implemented this year. This procedure improves the accuracy and precision of technician measurements of the chest-wall thickness needed for routine lung counting. Training was completed for all technicians on this new procedure.

\subsubsection{Counting Cell Safety}

A new liquid nitrogen (LN) sensing unit, developed at the IVRRF by Bruce Perkins of PNL, was installed in the chest counting rooms where auto-fill of LN occurs. An invention disclosure was filed for this sensor, which has increased the reliability for automatic shutdown of the LN filling systems.

\subsubsection{New Computer System for IVRRF Operations}

A requirements analysis and alternatives analysis were performed to identify the best computer system to support the IVRRF operations. An IBM RISC 6000 computer system was procured, which includes an optical disk for data storage. PNL Information Systems and Services has been awarded the task of designing and programming the software for the new system. 


\subsubsection{New Roof for the 747A Building}

A new roof was installed on the $747 \mathrm{~A}$ Building, which greatly reduced the chance of water damage to equipment from leaks.

\subsubsection{DOE Phantom Library}

The DOE Phantom Library, located at the IVRRF and administered by PNL, continued progress toward formal recognization by DOE. $\mathrm{A}^{133} \mathrm{Ba}$ Bottle Manikin Absorption (BOMAB) phantom, containing the radioactive material in a solid polyurethane matrix, was manufactured at PNL for the library. Several blank lung sets were also manufactured for use with the torso phantoms. The library now comprises 4 BOMAB calibration phantoms, 2 torso phantoms, 1 Fission Product Phantom $^{\otimes}, 11$ lung phantoms with various radionuclide loadings, 3 liver phantoms, and a skull phantom. (See Figure 3.2.)

During 1992, the software used for the Phantom Library database was upgraded from Paradox ${ }^{\mathrm{TM}}$ to FoxPro ${ }^{\mathrm{m}}$, due to problems with interfacing IVRRF hardware to the new database. The database is used to schedule phantom loans, maintain inventories, calculate the decay of the sources, and maintain client information for the library. A catalog of calibration phantoms was developed, and is currently being reviewed at DOE Headquarters. Even though no formal announcement of the opening of the library was made, twelve phantom loans were completed during 1992.

\subsection{SUPPORTING STUDIES}

The following studies were conducted by the In Vivo Measurement Program in 1992.

\subsubsection{Phantom Measurement Study}

A study of the attenuation characteristics and materials content of various PNL phantoms was undertaken in 1992, with the collaboration of the Canadian Bureau of Radiation and Medical Devices (BRMD). A torso phantom and several chest plate overlays were measured at McMaster Medical Center in Ottawa, Canada, using dual-photon absorptiometry to determine material density, thickness, and chemical content. The results of this preliminary study revealed nonuniformities in the density, material thickness, and/or the uniformity of material in the chest overlays and chest cover plate. Further studies are warranted to determine the nature of these irregularities. 
(a)

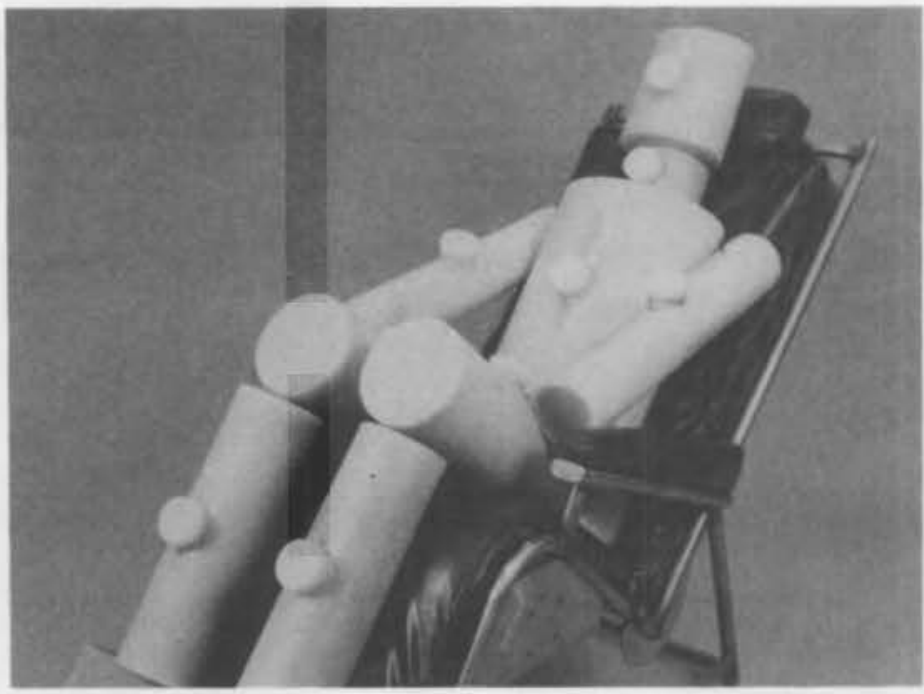

(b)

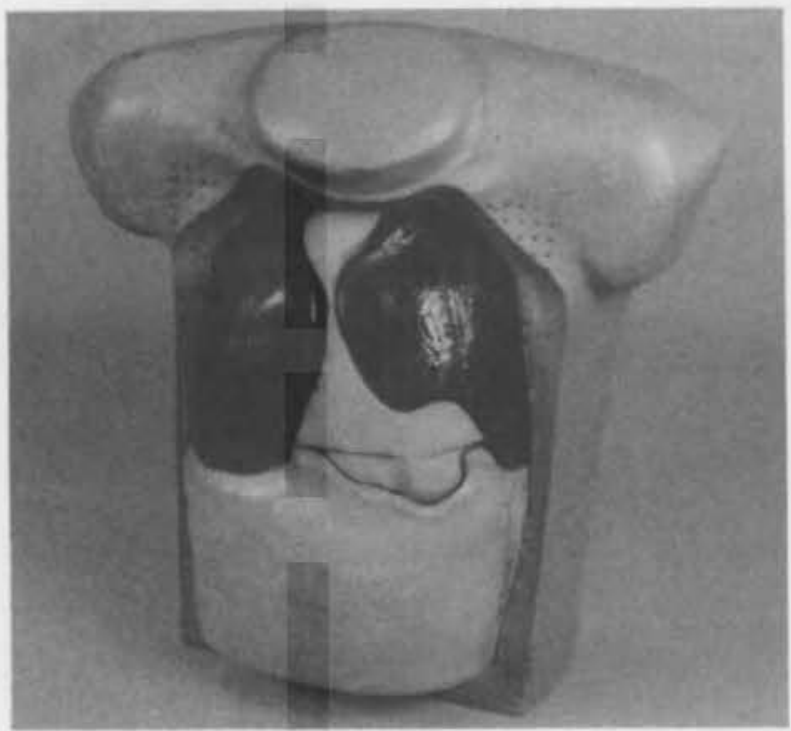

(c)

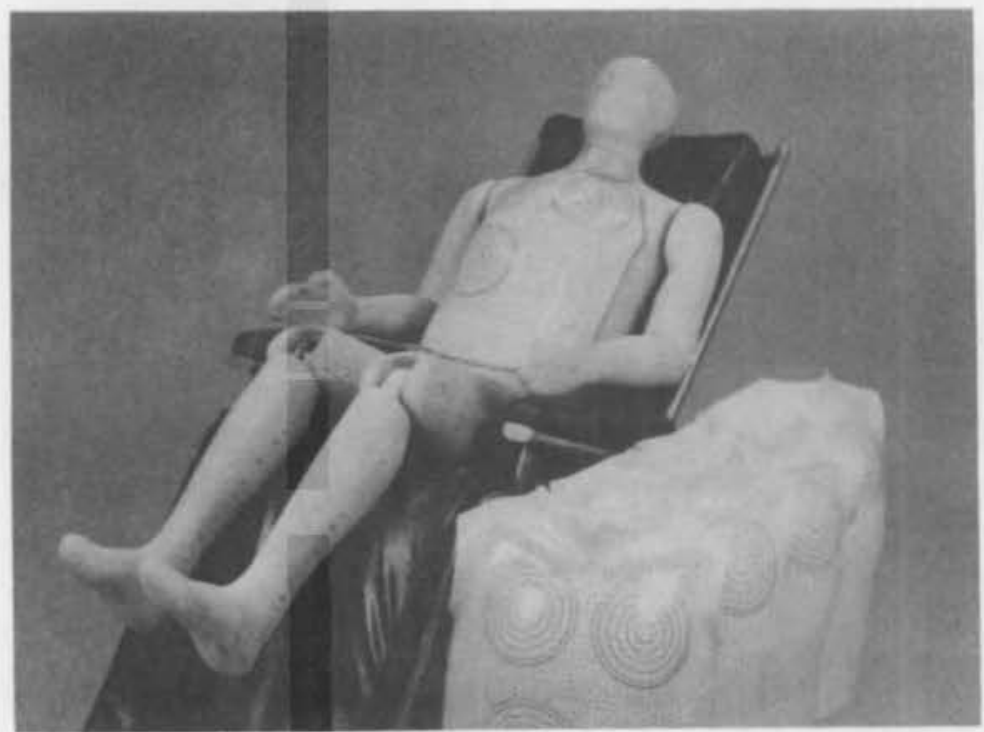

Figure 3.2. Various In Vivo Calibration Phantoms Available from the DOE Phantom Library, Administered by PNL. The phantoms are (a) a BOMAB whole-body phantom, (b) a torso phantom, and (c) a Fission Product Phantom ${ }^{\circledast}$. 


\subsubsection{U.S. Transuranium Registry Support}

A collaborative agreement was developed with the U.S. Transuranium Registery/U.S. Uranium Registery (USTR/USUR) at Washington State University (WSU) for measuring whole-body registered donors for the content of radioactivity in bone, tissue, and various organs. This longterm study will develop a database of measurements on donors while they are alive, and allow accurate comparisons to postmortem radiochemical results. Prolonged contract negotiations prevented any measurements from being completed in 1992.

\subsubsection{Detector Upgrades for Lung Counting}

A low-energy germanium (HpGe) detector was loaned to the IVRRF by EG\&G Ortec to evaluate the increased capabilities of the larger $(70 \mathrm{~mm})$ detector surface area. The detector, which has a diameter of $70 \mathrm{~mm}$, has adequate resolution and low-energy-noise characteristics for use with a new lung-counting system. A series of four measurements were made over a phantom and a blank subject to simulate a four-detector array. The results indicated that the detection level of the six-detector array was comparable with that of the simulated low-energy germanium-detector array. The unrestricted window diameter was found to be less than the diameter of the crystal. This information was given to the vendor so that the window could be redesigned. A window diameter at least as large as the crystal will increase efficiency and decrease the detection level. The decrease from six to four detectors will also reduce the repair and down time for the system.

\subsubsection{Intercomparisons of Calibration Phantoms}

Several intercomparisons of calibration phantoms from the DOE Radiological and Environmental Sciences Laboratory (RESL) in Idaho were completed during the year. These phantoms are potential DOELAP in vivo bioassay calibration phantoms that will be used for the performance testing of radiobioassay laboratories, per draft ANSI N13.30. Potassium -40 and ${ }^{137} \mathrm{Cs} /{ }^{60} \mathrm{Co}$ $\mathrm{BOMAB}$ phantoms were measured, as were ${ }^{241} \mathrm{Am}$ and ${ }^{232} \mathrm{Th}$ lung sets. Due to problems noted in the phantom construction, results of the $\mathrm{BOMAB}$ measurements were inconclusive. The gel filler material decomposed to a biphase liquid in several sections of the BOMAB phantoms. The calibrations developed using the RESL lung phantoms were similar to current PNL results.

\subsubsection{Caribou Meat Measurements for ${ }^{137} \mathrm{Cs}$}

Measurements of caribou meat from eastern Canada were made as a follow-up to a positive cesium case measured at the IVRRF. The subject stated that he routinely eats wild game. The measured cesium concentration was estimated at $4 \mathrm{nCi} / \mathrm{g}$ wet weight. Using the Code for Internal Dosimetry (CINDY), the $10 \mathrm{nCi}$ measured in the subject could be solely due to ingested game of the same concentration if he ate a $0.25-\mathrm{lb}$ meal of the meat once a week. The results of this study were presented at the annual Health Physics Society midyear conference in Cour d'Alene, Idaho. 


\subsection{PROGRAM-RELATED PROFESSIONAL ACTIVITIES}

Staff presentations, publications, and professional memberships during 1992 are listed in this section.

\subsubsection{Presentations}

Lynch, T. P. 1992. "Scanning Germanium Detection Systems for Total Body In Vivo Measurements." Presented at the 38th Annual Conference on Bioassay, Analytical and Environmental Radiochemistry, November 1-6, Santa Fe, New Mexico.

Lynch T. P., H. E. Palmer, and G. A. Rieksts. 1992. "Operation of a Remotely Operated In Vivo Counting System." Presented at the DOE Intercalibration Committee Meeting on Lung Counting, March 10-12, Las Vegas, Nevada.

Lynch, T. P., B. W. Perkins, and G. A. Rieksts. 1992. "Improving Reliability of Aged Germanium Detectors for In Vivo Counting." Presented at the 1992 Health Physics Society Annual Meeting in Columbus, Ohio, June 21-25, 1992.

Perkins B. W. 1992. "Handling and Repair of Intrinsic Germanium Detectors." Presented at the DOE Intercalibration Committee Meeting on Lung Counting, March 10-12, Las Vegas, Nevada.

\subsubsection{Publications}

Lynch, T. P., J. A. MacLellan, and D. E. Bihl. 1992. "In Vivo Bioassay Statement of Work." PNL-7011, Pacific Northwest Laboratory, Richland, Washington.

Mays, C. W., R. L. Aamodt, K. G. Inn, D. R. Brown, R. R. Greenburg, V. G. Iyengar, F. J. Schima, L. S. Slaback, J. W. Tracy, T. P. Lynch, and K. L. Mossman. 1992. "External Gamma-Ray Counting of Selected Tissues from a Thorotrast Patient." Health Phys. 63(1):33-40.

\subsubsection{Professional Memberships}

Lynch, T. P. Chairman of the ANSI N13.35 Working Group, which is writing the "American National Standard for the Bottle Manikin Absorption Phantom."

Lynch, T. P. Member of the ASTM Task Group E-10.04.27, which is writing a standard for "Estimation of Low Energy Photon Emitters in a Wound." 


\subsection{HANFORD EXTERNAL DOSIMETRY PROGRAM}

The Hanford External Dosimetry Program is a multifaceted effort involving all Hanford Site contractors. Dose-of-record information from external radiation for Hanford personnel is provided by this program, in compliance with the requirements set forth in the Hanford Site Radiological Control Manual, HSRCM-1 (RL 1992) and in DOE Orders 5480.11, "Radiation Protection for Occupational Workers" (1990), and 5480.15, "DOE Laboratory Accreditation Program for Personnel Dosimetry" (1987b). Dosimeter results from this program provide the means for contractor personnel to project, control, and measure radiation doses received by personnel. Program staff also provide Sitewide nuclear accident dosimetry in compliance with DOE 5480.11 requirements, and environmental dosimetry in support of PNL and Westinghouse Hanford Company (WHC) Environmental Surveillance Programs.

\subsection{EXTERNAL PERFORMANCE TESTING EVALUATIONS}

Three external reviews of the Hanford External Dosimetry Program were conducted during 1992, as discussed in the following subsections.

\subsubsection{WHC Blind Audit Dosimeters}

WHC routinely submits several audit dosimeters to be processed along with their personnel dosimeters. The PNL External Dosimetry Program successfully passed each monthly blind-audit dosimeter evaluation conducted by WHC during 1992. The program also passed each of the quarterly evaluations conducted by WHC using the DOE Laboratory Accreditation Program (DOELAP) methodology and criteria. During the entire year, no personnel dosimeter results exceeded established tolerance limits for the DOELAP-accredited testing categories. The results of these audits are provided by WHC to the Hanford Radiation Protection Historical Files.

\subsubsection{DOELAP Extremity Dosimetry Testing}

Hanford participated in DOELAP extremity pilot testing during 1992. Hanford passed all categories requested for testing with excellent performance. The testing was based on knowledge of the radiation source incident upon the dosimeter. Hanford's success demonstrates the capability to calibrate and interpret the dose in known laboratory exposure conditions. Table 4.1 indicates the response of the current Hanford extremity dosimeter. 
Table 4.1. Calibration Factors for Hanford Extremity Dosimeter

\begin{tabular}{lccl}
\hline Source & Tested Dose $(\mathrm{mR})$ & Calibration Factor $^{(\mathrm{a})}$ & DOELAP Category \\
\hline $\mathrm{M} 150$ & 500,000 & 0.6768 & Accident Category IA \\
${ }^{137} \mathrm{Cs}$ & 500,000 & 0.8072 & Accident Category IA \\
${ }^{\mathrm{M} 30}$ & 500 & 0.7899 & Protection Category IIA \\
${ }^{\mathrm{M} 150}$ & 500 & 0.7740 & Protection Category IIA \\
${ }^{137} \mathrm{Cs}$ & 500 & 0.9804 & Protection Category IIB \\
${ }^{90} \mathrm{Sr}$ & 500 & 1.1876 & Protection category IIIA \\
${ }^{204} \mathrm{Tl}$ & 500 & 15.1515 & Protection Category IIIA \\
$\mathrm{DU}$ & 500 & 1.8382 & Projection Category IID \\
\hline
\end{tabular}

(a) Dosimeter response multiplied by factor.

\subsubsection{Environmental Intercomparison Study}

PNL participated in a performance intercomparison of environmental dosimeters from the states of Washington and Oregon, the Washington Public Power Supply System, and the U.S. Nuclear Regulatory Commission. The PNL results compared very well with the laboratory given dose. The intercomparison study involved laboratory exposures provided by Oregon and by PNL, as well as a field monitoring site. The final report of the study has still not been received.

\subsection{THE ROUTINE PROGRAM}

In addition to dosimeter processing, the routine program for 1992 included implementation of an improved dose algorithm, completion of code modifications to routinely evaluate lower levels of detection, and formalization of a plan to update documentation on nuclear accident dosimetry.

\subsubsection{Routine Processing}

PNL processed 203,225 personnel dosimeters during 1992. This total includes processing of 90,302 personnel dosimeters (i.e., dosimeters actually worn by personnel) for which an official dose was reported to the Hanford Radiological Records Program. A reported zero result is considered an official dose. A summary of the minimum, maximum, and average monthly processing volume for each personnel dosimeter type is shown in Table 4.2. The maximum processing volume (23,395 dosimeters) occurred during January 1992, and included annually exchanged basic and multipurpose dosimeters. There are also multipurpose dosimeters that are exchanged on a quarterly basis. 
Table 4.2. Personnel Dosimeters Processed During 1992

\begin{tabular}{lrrrr}
\hline & \multicolumn{3}{c}{ Monthly Processing } & \\
\cline { 2 - 4 } \multicolumn{1}{c}{ Dosimeter } & Minimum & Maximum & Average & Annual Total \\
\hline Basic & 1,076 & 11,454 & 2,581 & 30,968 \\
Beta/Photon & 16 & 92 & 38 & 456 \\
Multipurpose & 2,040 & 10,521 & 3,670 & 44,043 \\
Extremity & 856 & 1,550 & 1,236 & 14,835 \\
\multicolumn{1}{c}{ Total } & & & & 90,302 \\
\hline
\end{tabular}

Total processing of 203,225 dosimeters vastly exceeds the 90,302 official dose results reported because of the following quality control practices, which are used to ensure the accuracy of the reported personnel dose:

- processing a minimum of two quality-control dosimeters within every 50 personnel dosimeters and every 25 dosimeters when determining chip sensitivity factors;

- reprocessing, prior to issue, any personnel dosimeter that has been stored more than 75 days to minimize environmental dose buildup;

- reprocessing any dosimeter with an observed reader count greater than 650 counts in any dosimeter position;

- conducting acceptance testing of new dosimeter inserts and holders; and

- updating chip sensitivity factors for dosimeters (i.e., processing is required both before and after irradiation).

Each year, numerous internal audit dosimeters are processed to ensure the integrity of dosimeter processing. During 1992, a total of 3,257 internal audit dosimeters were processed. A breakdown of the internal audit dosimeters is shown in Table 4.3. Control charts are used to evaluate the results for each of the audit dosimeter categories. Charts are prepared for every dosimeter and radiation type for each of the 13 dosimeter processings (e.g., every month, plus the year-end annual dosimeter processing) conducted each year. A quality control report is prepared for each processing. Copies are distributed to all Hanford Contractor radiation protection organizations, as well as to the Hanford Radiation Protection Historical Files. Copies of the control charts are also provided to the Historical Files. Changes in routine program practices occurred during 1992 , as discussed in the following subsections. 
Table 4.3. Audit Dosimeters Processed During 1992

\begin{tabular}{lcccc}
\hline & \multicolumn{4}{c}{ Dose Category ${ }^{(a)}$} \\
\cline { 2 - 5 } \multicolumn{1}{c}{ Dosimeter } & Shallow & Deep & Deep Neutron & Blank \\
\hline Basic & N/A & 400 & N/A & 180 \\
Beta/Photon & 130 & 65 & N/A & N/A \\
Multipurpose & 419 & 498 & 549 & 686 \\
Rings & N/A & 330 & N/A & N/A \\
\hline
\end{tabular}

(a) $\mathrm{N} / \mathrm{A}=$ Not applicable.

\subsubsection{Implementation of 1991 DOELAP-Tested Algorithm}

An improved dose algorithm was implemented, effective January 1992, based on the results of the 1991 DOELAP performance testing (Lyon et al. 1992). This was approved by the Hanford Personnel Dosimetry Advisory Committee, ${ }^{(a)}$ based on a comparison of calculated dose using the previous and the improved algorithms for Hanford personnel. The comparison showed little difference in cumulative or individual dose. There was an expected small variation in the cumulative dose because of the difference in dose-reporting protocol between Hanford and DOELAP. For many years, Hanford has used a procedure to round doses to the nearest multiple of $10 \mathrm{mrem}$; in contrast, DOELAP reports doses to the nearest mrem. A letter was written to inform the DOELAP Performance Testing Administrator of this change.

\subsubsection{Code Modifications for Lower-Level-of-Detection Analysis}

Code modifications were completed to routinely evaluate the lower level of detection for calibration and audit dosimeter data for each dosimeter processing. Sixteen categories of audit exposure are routinely evaluated for Hanford basic, multipurpose, and beta/photon audit dosimeters. During 1992, the lower level of detection was less than 10 mrem for all categories.

(a) Fix, J. J. "Minutes of Hanford Personnel Dosimetry Advisory Committee Meeting on January 23, 1992." Letter to Distribution, dated January 27, 1992. (A copy is available in the Hanford Radiation Protection Historical Files, Pacific Northwest Laboratory, Richland, Washington.) 


\subsubsection{Plan for Updating Documentation for Nuclear Accident Dosimetry}

In conjunction with PNL and WHC radiation protection staff, a plan has been formalized to update the manual Location of Criticality Alarms and Nuclear Accident Dosimeters at Hanford $d^{(\mathrm{a})}$ every two years. Current copies of this manual were desired during a Defense Nuclear Facilities Safety Board review of WHC. Although the information was current, an established period to update the documentation, as required by DOE 5480.11 (1990), was not formalized. This requirement is now included in DOE program planning and is explicitly stated in the updated copy of the manual.

\subsubsection{Revised Documentation}

Nearly all of the documentation for the Hanford External Dosimetry Program was updated during 1992. Formal documentation is contained in two PNL manuals:

- Location of Criticality Alarms and Nuclear Accident Dosimeters at Hanford, ${ }^{(a)}$ and - Hanford External Dosimetry Program. ${ }^{(b)}$

In addition to these manuals, the External Dosimetry Program staff maintains eight internal technical documents describing the design, algorithm, calibration, and dose-response characteristics of the different dosimeters, as well as procedures for evaluating the nuclear accident and environmental dosimeters. The most recent revision date is given for each document.

Volume I, Quality Assurance, 1992, W. V. Baumgartner

Volume II, Personnel Dosimeter Features, Calibration and Dose Assessment, 1991, A. W. Endres

Volume III, Data Processing, 1992, J. A. Schur

Volume IV, Nuclear Accident Dosimerry, 1992, S. R. Reese

Volume V, Dosimeter Reader Systems, 1991, W. V. Baumgartner

Volume VI, Field Measurements, 1991, A. W. Endres

Volume VII, Environmental Dosimerry, 1992, A. W. Endres

Volume VIII, Laboratory Procedures, 1992, J. D. Peters

These documents are used to administer the External Dosimetry Program. In addition, letter reports are prepared and submitted to the Hanford Personnel Dosimetry Advisory Committee for review and comment for significant program issues. Copies are included in the minutes of these committee meetings and provided to the Hanford Radiation Protection Historical Files maintained by the Hanford Radiological Records Program.

(a) Internal manual, PNL-MA-583, Pacific Northwest Laboratory, Richland, Washington.

(b) Internal manual, PNL-MA-568, Pacific Northwest Laboratory, Richland, Washington. 


\subsection{NEW THERMOLUMINESCENT AND TRACK-ETCH DOSIMETRY SYSTEMS}

After approximately three years of effort, a procurement for a commercial thermoluminescent dosimetry (TLD) system was placed in 1992. This system, along with the development of a track-etch dosimetry (TED) system, will form the basis of the future Hanford personnel dosimetry system. Work completed for the new system during the past year is described in this section.

\subsubsection{Thermoluminescent Dosimetry System}

A Harshaw TLD system has been procured. The system will consist of four model 8800 hot-gasreader systems. The procurement includes approximately 55,000 model 8825 multipurpose dosimeters. These dosimeters have shown excellent performance in the DOELAP categories for beta-, photon-, and mixed-radiation testing. In addition, these dosimeters possess the capability to indicate whether any neutron exposure is received by the dosimeter, even though the dosimeter is not intended for use in neutron fields. Approximately 10,000 model 8816 neutron dosimeters are also part of the procurement. The model 8816 TLD and the Hanford TED system will be used to form the Hanford combination TLD/TED personnel neutron dosimeters. Harshaw extremity and environmental dosimetry systems were also included in the procurement.

\subsubsection{Track-Etch Dosimetry System}

An operational TED counting laboratory was established in the 318 Building. This system has been used to conduct routine evaluation of the prototype TLD (existing)/TED dosimeter measurements beginning during August 1993. Laboratory support to etch the TEDs continues to be located in the Research Technology Laboratory (RTL) Building.

\subsection{SUPPORTING STUDIES}

Several supporting studies were conducted by External Dosimetry Program staff during 1992. These are described in the following subsections.

\subsubsection{Nuclear Accident Dosimetry}

Code development was completed to transfer routine data support for thermoluminescent dosimetry phosphors, used in Hanford nuclear accident dosimeters (NADs), to the External Dosimetry VAX system. Previously, the work was done at the IBM/PC level using dBase III programming. Transfer to the VAX system was preferred because it further centralizes dosimetry code support to this system. In addition, updated calibration of the NAD spectroscopy system was completed and documented. The results of the calibration demonstrated compliance with all requirements of DOE $5480.11(1990)$. However, it is necessary to use phosphor-specific sensitivity factors to obtain the required precision. 


\subsubsection{Prototype Combination TLD/TED Personnel Neutron Dosimeters}

An effort begun during December 1990 to routinely assign prototype combination TLD/TED (thermoluminescent dosimeter/track-etch dosimeter) personnel neutron dosimeters to seven personnel working in neutron field environments was continued throughout 1992. Elements of this effort were discussed in the previous annual report (Lyon et al. 1992). Dosimeters were exchanged monthly for all employees. The results obtained during 1992 further confirm the results obtained previously. The TLD results continue to be significantly greater than the TED results. The work environment in which these dosimeters are being used is highly scattered, with the energy of the majority of neutrons being less than about $150 \mathrm{keV}$. Data from field measurements conducted during 1991 should be used in the interpretation of this data (Brackenbush, Baumgartner, and Fix 1991). For this field environment, the TLD overestimates the dose and the CR-39 underestimates the dose.

\subsubsection{Quality Control Report}

Elements of the External Dosimetry quality control program for routine dosimeter processing were documented during 1992 (Baumgartner, Endres, and Reese 1992). These elements are used to ensure that the reported doses for audit and control dosimeters meet DOELAP performance criteria, as well as more rigid internal program goals. The report describes procedures used for dosimeters and processing equipment.

\subsection{PROGRAM-RELATED PROFESSIONAL ACTIVITIES}

Staff presentations, publications, and professional memberships during 1992 are listed in this section.

\subsubsection{Presentations}

A. W. Endres presented "Current Status of the Department of Energy and Health Physics Society Draft Extremity Standards" at the Harshaw Users' meeting in San Antonio, Texas, November 9-13, 1992.

J. J. Fix presented an overview of the Hanford External Dosimetry Program to members of the Defense Nuclear Facility Safety Board on March 31, 1992.

J. J. Fix presented an overview of Hanford dosimetry systems, dose assessment, and uncertainty at a meeting of the Hanford Mortality Study Advisory Committee in Seattle, April 14-15, 1992.

J. J. Fix presented a poster session entitled "Consistency of External Dosimetry in Epidemiologic Studies of Nuclear Workers," coauthored with Ethel Gilbert, at the International Radiation Protection Society meeting in Montreal, May 18-22, 1992. 
S. R. Reese presented a paper entitled "Quality Control Program for the Hanford External Dosimetry Thermoluminescent Processing System," coauthored with W. V. Baumgartner and

A. W. Endres, at the annual Health Physics Society meeting in Columbus, Ohio, June 21-26, 1992.

\subsubsection{Publications}

Baumgartner, W. V., A. W. Endres, and S. R. Reese. 1992. Quality Control Program for the Hanford External Dosimetry Thermoluminescent Processing System. PNL-8299, Pacific Northwest Laboratory, Richland, Washington.

Fix, J. J., E. S. Gilbert, R. H. Wilson, W. V. Baumgartner, and L. L. Nichols. 1992. "Comments on 'Evidence of Biased Recording of Radiation Doses of Hanford Workers.'" Am. J. Indust. Med. 22:281-283.

\subsubsection{Professional Memberships}

Endres, A. W., and J. J. Fix. Members of the DOE ad hoc working group to develop a standard for extremity dosimeter performance.

Fix, J. J. Chairperson of the DOE Comprehensive Epidemiologic Data Resource (CEDR) dosimetry working group.

Fix, J. J. Chairperson of the International Agency for Research on Cancer (IARC) dosimetry committee to pool existing epidemiological studies from the U.S. (including Hanford), Canada, and the United Kingdom.

Fix, J. J. Member of the DOELAP Oversight Board, as identified in DOE 5480.15, "Department of Energy Laboratory Accreditation Program for Personnel Dosimetry."

Fix, J. J. Member of the Health Physics Society Standards Committee. 


\section{5,0 INSTRUMENT CALIBRATION AND EVALUATION PROGRAM}

The Instrument Calibration and Evaluation Program provides a complete radiation protection instrument service, which is an integral part of radiation protection at the Hanford Site. This program provides the Hanford contractors with a high-quality, reliable, and accurate instrumentation pool capable of performing at the level necessary to ensure personnel safety, as required by DOE 5480.11, "Radiation Protection for Occupational Workers" (1990), and the Hanford Site Radiological Conrrol Manual, HSRCM-1 (RL 1992). Calibrations are performed using the guidance in ANSI N323, Rodiarion Protecrion Instrumentarion Test and Calibration (1978). The routine program for $\mathrm{CY} 1992$ comprised four basic tasks: 1) maintaining the routine portable instrument pool, 2) conducting the Hanford Instrument Evaluation Program, 3) calibrating Westinghouse Hanford Company (WHC) 200-Area continuous air monitors, and 4) updating and revising the Site Radiation Protection Instrument Manual. ${ }^{\text {tal }}$ These basic tasks and other important supporting tasks performed in CY 1992 are described in this chapter.

\subsection{THE ROUTINE PROGRAM}

As part of the complete radiation protection instrument program provided by the routine program, a pool of portable and semiportable radiation protection instrumentation is maintained for contractor use. Maintaining this instrumentation pool involves

- procuring new and replacement instruments;

- overseeing an instrument pickup and delivery service;

- maintaining calibration records; and

- surveying, decontaminating, maintaining, and calibrating instruments.

The routine program also includes the following activities:

- maintaining traceability of radiological and electronic calibration systems to NIST;

- operating a program to service radiation protection emergency kits;

- modifying and updating written calibration procedures as new instruments are introduced and calibration techniques are improved;

- procuring, acceptance testing, calibrating, and distributing pencil dosimeters;

(a) Internal manual, MNL-MA-562, pacific Northe laboratory, Richland, Washington. 
- performing specification development and acceptance testing on all instruments purchased for pool use, as required by Hanford contractors; and

- fabricating and certifying instrument performance checksources for Hanford contractors.

\subsubsection{Routine Portable Instrument Pool}

The use of portable instruments by contractors on the Hanford Site during CY 1992 is shown in Table 5.1. The instrument types are described in detail in the Radiation Protection Instrument Manual. ${ }^{\text {(a) }}$

During the year, a number of new instruments were procured to replace instruments damaged or discarded because of contamination. Additional contamination-monitoring instruments and lowlevel-gamma-field instruments were also procured, in response to the change in Site mission from plutonium production to restoration and remediation. The following items were purchased in 1992:

- 225 Geiger-Mueller (GM) Pancake probes and 150 portable alpha monitors (PAMs), which are alpha-contamination-sensitive probes;

- $760 \mathrm{GM}$ tubes for probe repairs and replacement parts; and

- 600 low-range $(0-200 \mathrm{mr})$ and 200 medium-range $(0-500 \mathrm{mr})$ direct-reading pencil dosimeters.

As part of a complete portable instrument program, design and procurement activities continued for multirange checksource devices needed to verify the performance of instruments in the field, as required by ANSI standards and DOE orders. Checksource devices for the GM Pancake survey meters, the PAMs, and the MICRO REM low-range gamma survey meters were specified for procurement, and initial deliveries were received. To complement these devices and the existing Site instrument checksources, annual verification and recertification of the checksources continued. The source calibration capabilities of the Calibration and Evaluation Program allow for the recertification of sources. Three counting systems provide this source certification service:

- a Nuclear Measurements Corporation (NMC) windowless proportional detector;

- an Eberline proportional portal monitor detector; and

- a Berthold large-area (8-inch diameter) flow-through proportional counting system.

(a) Internal manual, PNL-MA-562, Pacific Northwest Laboratory, Richland, Washington. 
Table 5.1. Portable Instrument Use by Hanford Contractors in 1992

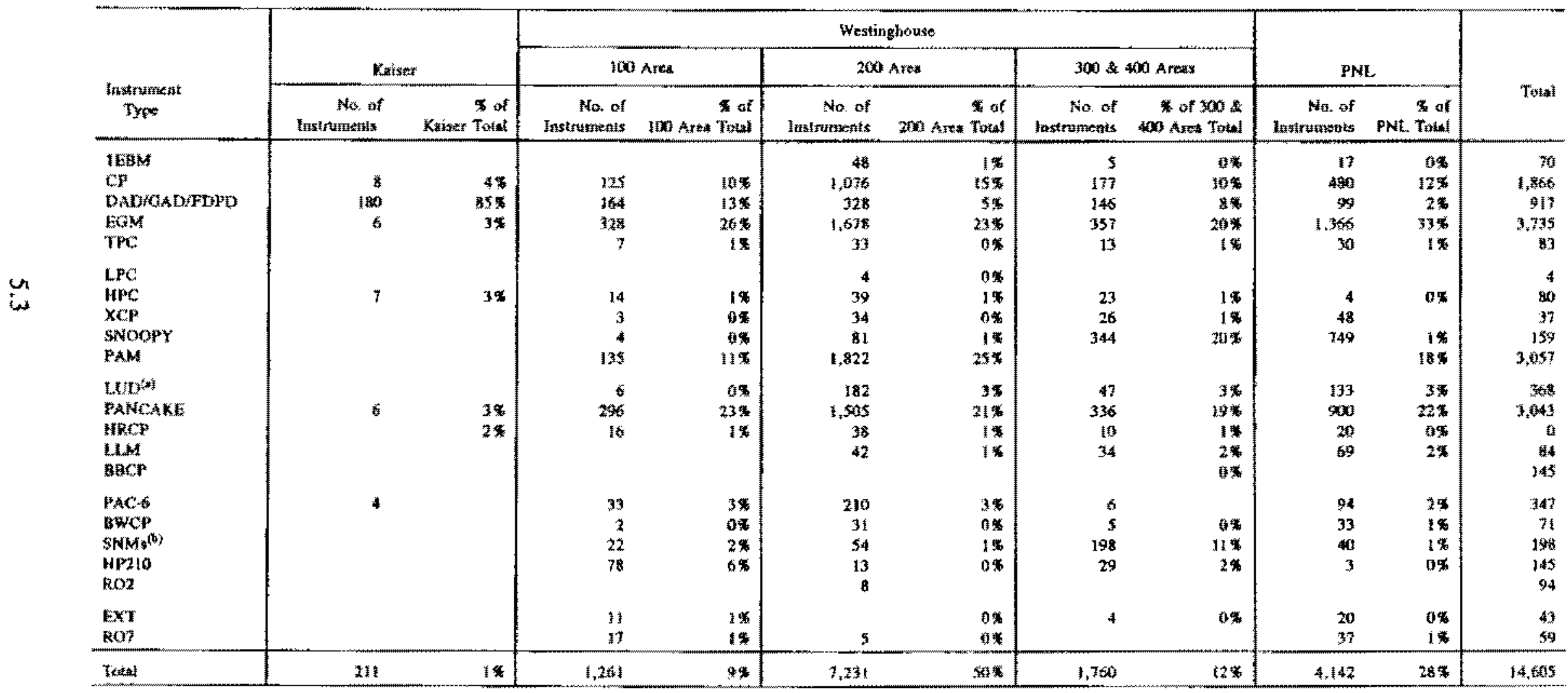

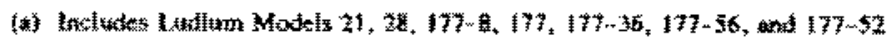

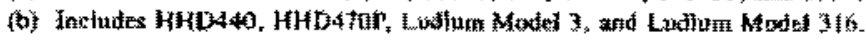




\subsubsection{Hanford Instrument Evaluation Program}

The Hanford Instrument Evaluation Committee (HIEC) was established to provide a Hanford intercontractor information exchange mechanism, to assure that the highest quality portable and semiportable radiological protection instrumentation program is maintained at Hanford.

Responsibilities of the committee include

- discussing and proposing solutions to ongoing or potential radiological instrumentation problems and needs on site;

- identifying new radiological instrumentation available from manufacturers that may be useful to the Hanford Site operations;

- overseeing the procurement of the instruments, and reviewing the evaluations of the performance by contractor organizations;

- establishing or reviewing minimum acceptable operational criteria for portable and semiportable radiological instrumentation used for safety on the Hanford Site; and

- promoting information exchange between contractors on radiological protection instrumentation usage and problems/resolutions.

Representatives from all the Hanford contractors and a DOE representative are on this committee. During 1992, a Senior Research Scientist position was added to the HIEC to serve as chairperson and to manage the evaluation and testing of existing and new Site radiological control instrumentation, as directed by the DOE Radiological Control Manual (1992).

\subsubsection{Calibration of WHC 200-Area Alpha CAMs}

PNL began assuming the calibration of all continuous air monitors (CAMs) in the 200-Area in September 1989, in response to a letter written by A. J. Rizzo (Assistant Manager for Operation at RL) to J. E. Nolan (President of WHC). In August 1990, PNL was calibrating $100 \%$ of the alpha CAMs. The program continued successfully through CY 1992 and has become a part of the routine calibration program of PNL.

\subsubsection{Instrument Manual Update}

The Instrument Calibration and Evaluation Program provides the Radiation Protection Instrument Manual $^{(a)}$ to provide the radiological protection technologists (RPTs) with specific information for operating and using monitoring instruments available through the Hanford instrument pool.

(a) Internal manual, PNL-MA-562, Pacific Northwest Laboratory, Richland, Washington. 
During 1992, the Program completed the drafts of sections on alpha and beta CAMs. HSRCM-1 (RL 1992) and the instrument source certification program have added requirements for the CAM sections that will need to be resolved.

\subsection{PROGRAM CHANGES IN 1992}

The following changes occurred in the routine program of the Calibration and Evaluation Program in 1992.

\subsubsection{Calibration and Evaluation Program Policy Development}

In June 1992, DOE issued the Radiological Control Manual, which is the DOE complex-wide manual for radiological control. Individual DOE sites, such as Hanford, produced a site control manual. The Hanford control manual, HSRCM-1 (RL 1992), was issued in December. During this period, the Calibration and Evaluation Program was developing a policy statement. Because HSRCM-1 drove radiological support operations, such as instrument calibration, the policy statements that were drafted for the preface to the Radiological Calibration Procedures ${ }^{(a)}$ were initial policy statements only.

\subsubsection{Calibration Records Database Management}

During 1992, the Calibration and Evaluation Program assumed the financial support of the HP-9000 computer database management. The HP-9000 computer in the 318 Building facility is used primarily for the radiological-control instrument-calibration database.

\subsection{SUPPORTING STUDIES}

Special studies and investigations conducted by the Calibration and Evaluation Program are described in the following subsections.

\subsubsection{Testing and Evaluation of a New Generation of Alpha CAMs}

CAMs are an integral part of Hanford safety programs designed to protect workers from airborne radioactive materials. However, because of the strong and highly variable nature of natural radon backgrounds at many Hanford facility sites, it has been impractical to operate existing plant alpha CAMs at the 8-DAC-hour sensitivity required by DOE 5480.11 (1990), due to excessive false alarm rates. A joint PNL-WHC effort to functionally evaluate and field test a new generation of alpha CAMs was completed in CY 1992. The new alpha CAMs have greater background discriminating capabilities than instruments currently in use. Initial efforts to procure the selected alpha CAM model were initiated in 1992.

(a) Internal manual, PNL-MA-563, Pacific Northwest Laboratory, Richland, Washington. 


\subsubsection{Technical Review of WHC CAM Calibration Procedures}

Because of the extraordinary weight of the beta CAMs, RL has allowed wHC to calibrate its beta CAMs at its site shops rather than transporting them to the PNL Calibration Facility. At the direction of RL, the Calibration and Evaluation Program assisted with and reviewed the procedure revisions to assure that the site calibrations of the beta CAMs were comparable to the PNL facility calibration.

\subsection{PROGRAM-RELATED PROFESSIONAL ACTTVTTIES}

Program staft held the following professional memberships during 1992:

Johnson, M. L. Chairperson of the Subcommittee on Alpha CAM Procurement for the DOE Operating Contractors' Working Group on Air Monitoring.

Johnson, M. L. Chairperson of the Working Group for ANSI N323B, "Radiation Protection Instrumentation Test and Calibration-Air Monitoring Instruments."

Johnson, M. L. Member of the Working Group for ANSI N323A, "Radiation Protection Instrumentation and Calibration-General Requirements and Portable Instruments."

Johnson, M. L. Member of the Working Group for ANSI N323C, "Radiation Protection Instrumentation and Calibration--Fixed Instruments." 


\subsection{RADIATION STANDARDS AND CALIBRATIONS PROJECT}

The primary function of the Radiation Standards and Calibrations (RS\&C) Project is to maintain radiological standards necessary to facilitate appropriate characterizations and calibrations within the Hanford Instrument Calibration and External Dosimetry Programs. Although funded for several years through the Office of Hanford Environment, this project was reorganized in October 1992 as a subtask of the Instrument Calibration and Evaluation Program. This change in funding source is transparent to project goals and operations.

The RS\&C Project maintains special equipment for characterizing instrument and dosimeter response, and supplemental radiological reference fields, as necessary. This activity provides the means to characterize response to various radiation fields encountered at Hanford and ensures that calibration fields are provided in accordance with recommended standards and guidelines. Typical project activities include

- $\quad$ providing traceability of the calibration sources to NIST;

- maintaining basic radioactive sources and instruments that serve as radiological standards;

- reviewing calibration standards, regulations, and handbooks; and

- ensuring that calibration procedures are in agreement with technically accepted methods.

Project activities conducted during CY 1992 are discussed in this chapter.

\subsection{THE ROUTINE PROGRAM}

Activities in the routine program included maintaining radiological standards and capabilities, and performing calibrations and constancy checks.

\subsubsection{Standards and Capabilities}

The radiological standards and capabilities maintained for the various entities of Hanford Radiological Protection Support Services include gamma, beta, and neutron isotopic sources, as well as $\mathrm{x}$-ray generating devices. These standards and capabilities are configured to deliver wellknown, and easily reproduced, quantities of radiation dose or exposure to environmental and personnel dosimeters, radiological survey instruments, and laboratory reference devices for calibration and/or response characterization.

Photon and beta sources are periodically intercompared with NIST, either through the use of transfer standard instruments submitted by NIST or from direct measurements by NIST personnel within the PNL facility. Neutron sources undergo direct calibration at the NIST facility prior to being placed into service at PNL. 


\subsubsection{Gamma Ray Photon Sources}

Available photon sources include various activities of ${ }^{137} \mathrm{Cs}$ and ${ }^{60} \mathrm{Co}$ configured in collimatedbeam, well, or open field geometries, and a single ${ }^{241} \mathrm{Am}$ source configured for irradiation in a $2 \pi$ geometry, as listed in Table 6.1.

The "open" sources listed in Table 6.1 are placed in the center of a circular aluminum table, via a pneumatic air system. Two discrete distances to the source are typically characterized.

"Beam" sources, with the exception of 318-131, provide a continuum of exposure rates via use of a target positioning stand located on a sliding rail system. Source 318-131 also includes a moveable target stand, but is typically characterized and used at either $1-\mathrm{m}$ or $3-\mathrm{m}$ distances. Target (instrument and/or dosimeter) placement for the most commonly used positions within these beam irradiation facilities is enhanced by laser alignment capabilities. "Well" sources also provide a continuum of exposure rates, and facilitate instrument adjustments during irradiation without undue exposure to personnel. Source-to-target distance is controlled by moving the sources on a trolley system up and down within the well (see Figure 6.1), via computer interface.

Table 6.1. Available Photon Isotopic Sources

\begin{tabular}{rccccc}
\hline \multirow{2}{*}{ Source } & Geometry & $\begin{array}{c}\text { Exposure Rate/Range, } \\
\text { R/h }\end{array}$ & $\begin{array}{c}\text { Room No. } \\
\text { in }\end{array}$ & $\begin{array}{c}\text { Reference } \\
\text { No. }\end{array}$ & $\begin{array}{c}\text { Primary Photon } \\
\text { Energy (MeV) }\end{array}$ \\
\hline \multirow{2}{*}{${ }^{60} \mathrm{Co}$} & Well & $0.006-2.000$ & 121 & $318-027$ & $1.17 / 1.33$ \\
& Open & $2 / 7$ & 106 & $318-164$ & $1.17 / 1.33$ \\
& Beam & $10-300$ & 8 & $318-037$ & $1.17 / 1.33$ \\
& Beam & $90-3000$ & 8 & $318-036$ & $1.17 / 1.33$ \\
\hline \multirow{2}{*}{} & Well & $0.002-0.100$ & 121 & $318-031$ & 0.662 \\
& Well & $0.040-10.000$ & 121 & $318-030$ & 0.662 \\
& Beam & $0.100-30.000$ & 8 & $318-040$ & 0.662 \\
& Open & $0.400 / 2.000$ & 106 & $318-001$ & 0.662 \\
& Beam & $1-300$ & 8 & $318-044$ & 0.662 \\
& Open & $1 / 8$ & 106 & $318-029$ & 0.662 \\
& Beam & $3 / 30$ & 6 & $318-131$ & 0.662 \\
\hline${ }^{137} \mathrm{Am}$ & Open $(2 \pi)$ & 0.125 & 6 & $318-184$ & 0.060 \\
\hline
\end{tabular}

(a) Nominal. 


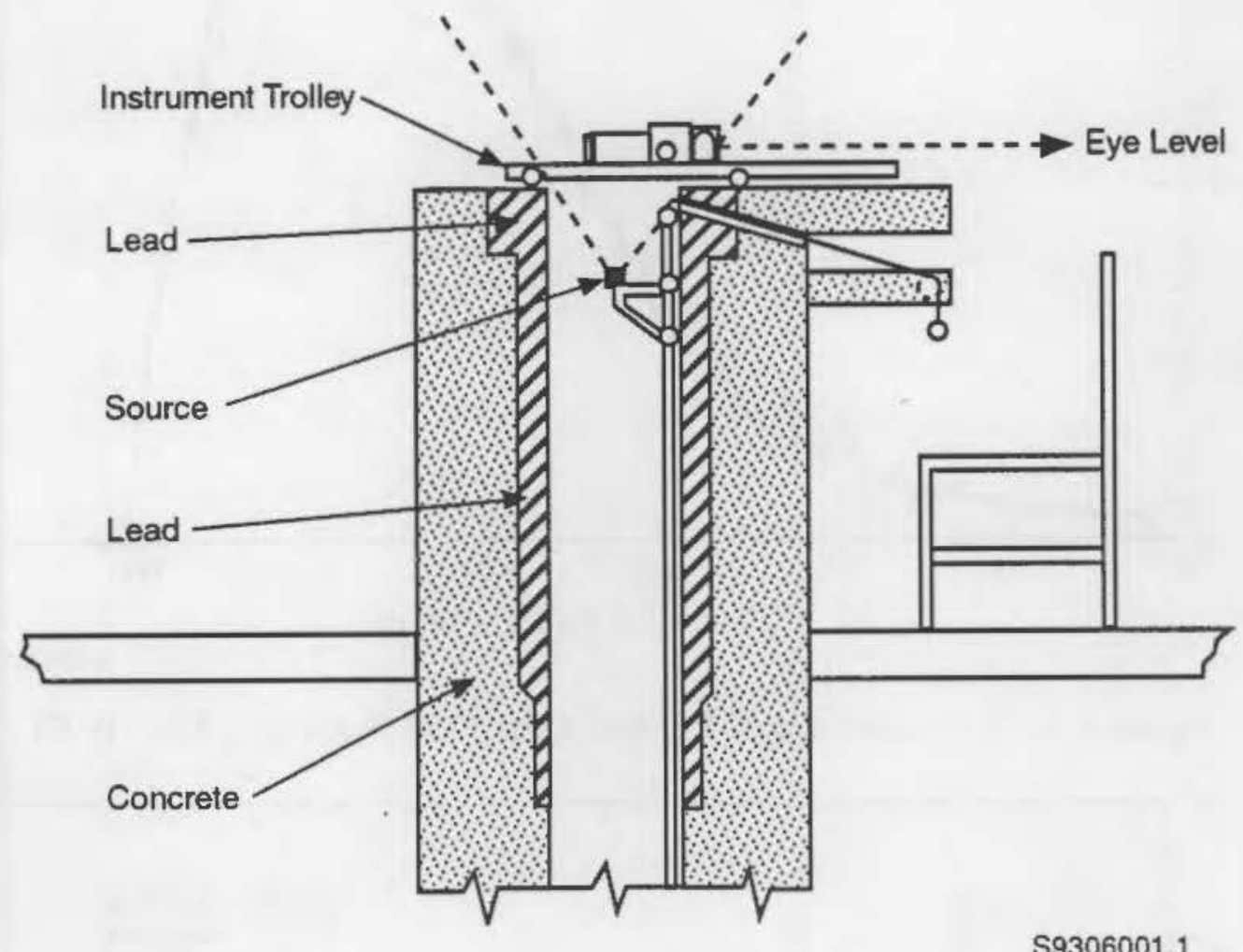

S9306001.1

Figure 6.1. Typical Calibration Well

\subsubsection{X-Ray Photon Sources}

Two identical Philips Model-324 $\mathrm{x}$-ray machines are currently in use in support of the RS\&C Project. One machine is used to produce Bremsstrahlung (broad) photon spectra (e.g., NIST techniques M30, S60, M150, and H150). The second machine is configured to facilitate production of K-fluorescence technique (narrow) secondary photon spectra (e.g., K16 and K59) within a shielded enclosure, known as a "HOG." Figures 6.2 and 6.3 show a sample spectrum of each type of $\mathrm{x}$-ray configuration. A complete listing of available techniques and their characteristics is provided in Table 6.2. Both systems include laser alignment capability to aid in target (instrument/dosimeter) positioning. 


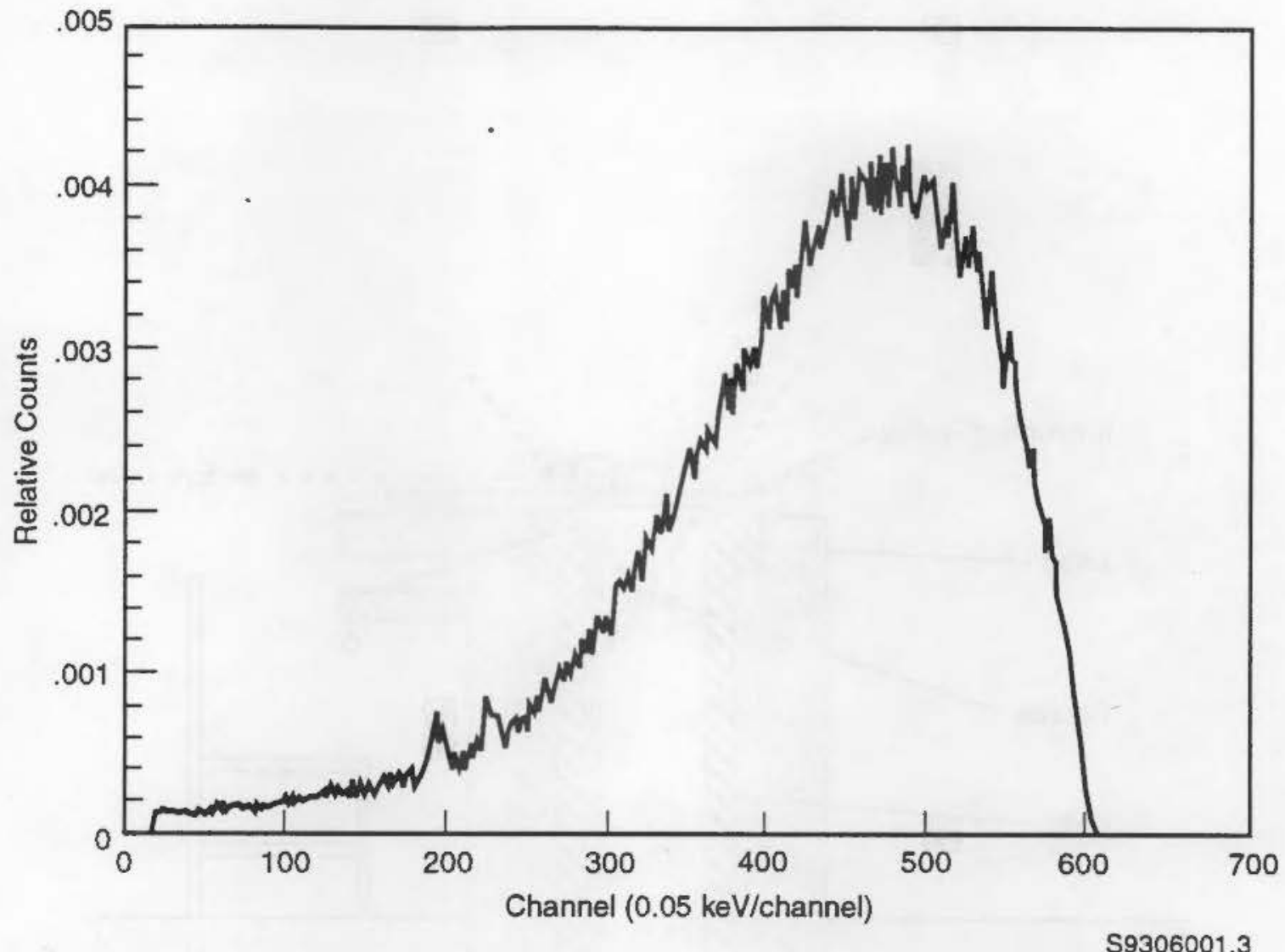

Figure 6.2. Bremsstrahlung X-Ray Spectrum (M30 Technique, April 1992)

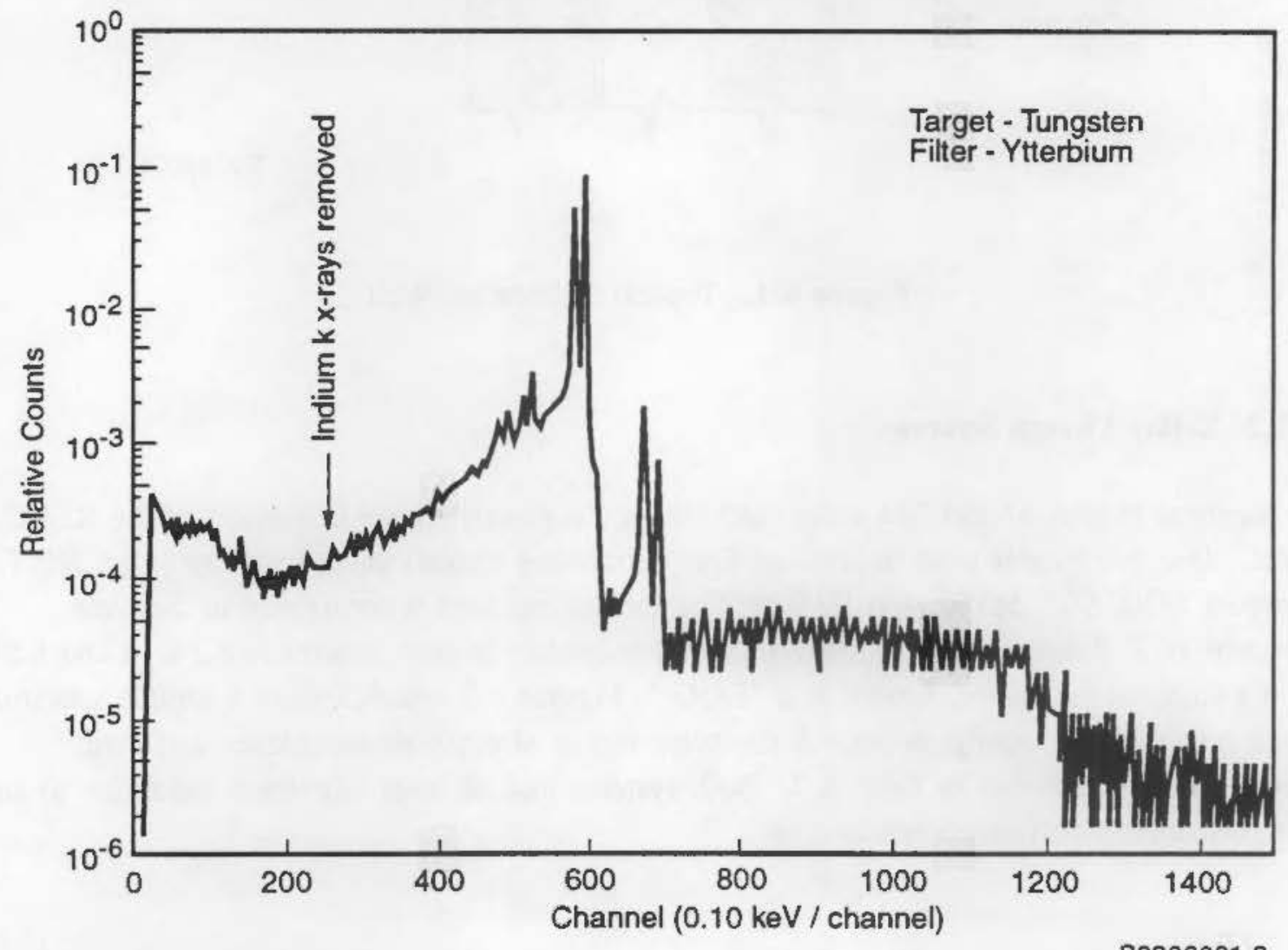

Figure 6.3. K-Fluorescence X-Ray Spectrum (K59 Technique, April 1992) 
Table 6.2. Available X-Ray Photon Techniques

\begin{tabular}{|c|c|c|c|c|c|}
\hline Style & Technique & $\begin{array}{c}\text { Average/ } \\
\text { Effective } \\
\text { Energy }(\mathrm{keV})^{(\mathbf{a})}\end{array}$ & $\begin{array}{c}\text { Half Value } \\
\text { Layer } \\
(\mathrm{mm} \mathrm{Al})\end{array}$ & $\begin{array}{l}\text { Homogeneity } \\
\text { Coefficient }\end{array}$ & $\begin{array}{c}\text { Exposure } \\
\text { Rate/Range } \\
(\mathbf{R} / \mathbf{h})^{(\mathbf{a})}\end{array}$ \\
\hline \multirow{14}{*}{ Bremsstrahlung } & M20 & 12.8 & 0.150 & 0.790 & $2.9-288.6$ \\
\hline & $\left.\mathrm{M} 30^{\mathrm{b}} \mathrm{b}\right)$ & 20 & 0.354 & 0.634 & 3.2 .326 .1 \\
\hline & 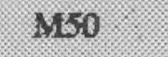 & 29 & 0.976 & 9.650 & $3.4 \cdot 350.9$ \\
\hline & M180 & 51 & 4.86 & 0.720 & $1.5-305.0$ \\
\hline & 11150 & 20 & 9.90 & 0.862 & $3.8 \cdot 391.4$ \\
\hline & M200 & 84 & $N / A^{(c)}$ & N/A & $4.3-431.0$ \\
\hline & $\$ 60$ & 36 & 2.12. & 0.760 & $0.6-119.6$ \\
\hline & S75 & 39 & 1.81 & 0.610 & $4.6 \cdot 472.2$ \\
\hline & H50 & 38 & N/A & N/A & $0.05-9.40$ \\
\hline & $\mathrm{H} 100$ & 70 & 13.47 & 0.964 & $0.02-3.07$ \\
\hline & $H 150$ & 128 & 16.71 & 0,020 & $0.12 \times 16.6$ \\
\hline & $\mathrm{H} 200$ & 167 & 20.22 & 0.994 & $0.09-9.22$ \\
\hline & $\mathrm{H} 250$ & 210 & 22.48 & 0.987 & $0.09-8.50$ \\
\hline & Н300 & 252 & 23.87 & 0.898 & $0.06-5.63$ \\
\hline \multirow{7}{*}{ K-fluorescence } & K8.6 & 8.6 & N/A & N/A & 20.43 \\
\hline & $11 \% 0$ & 17.5 & N. & $N i$ & 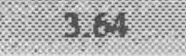 \\
\hline & K25.3 & 25.3 & N/A & N/A & 3.74 \\
\hline & $\mathrm{K} 31.0$ & 31.0 & N/A & N/A & 1.55 \\
\hline & K40.1 & 40.1 & N/A & N/A & 1.51 \\
\hline & K49.1 & 49.1 & N/A & N/A & 0.86 \\
\hline & KS9.0 & 59.3 & $\mathrm{NA}$ & $N / 4$ & 0.96 \\
\hline
\end{tabular}

(a) Nominal.

(b) Routine calibration is maintained only for shaded techniques.

(c) N/A = Not applicable.

\subsubsection{Neutron Sources}

Two configurations of ${ }^{252} \mathrm{Cf}$ neutron sources are available. The first configuration allows the use of two sources within the pneumatic transfer system in Room 106 . When used, these sources are placed roughly in the geometric center of a room $10-\mathrm{m}$ in width, $14-\mathrm{m}$ in length, and $8.8-\mathrm{m}$ in height, such that a low scatter environment is established. Both sources may be used either bare 
or moderated by a sphere of deuteriated water $\left(\mathrm{D}_{2} \mathrm{O}\right) 15 \mathrm{~cm}$ in radius and covered by $0.051 \mathrm{~cm}$ of cadmium. These sources provide neutron fields useful for instrument calibrations, as well as for dosimeter characterization in accordance with specifications of DOE/EH-0027, Department of Energy Standard for the Performance Testing of Personnel Dosimetry Systems (1986), and ANSI N13.11, American National Standard for Dosimetry - Personnel Dosimetry Performance Criteria for Testing (1983). Sources were calibrated in terms of neutron emission rate at NIST prior to receipt and installation.

The second configuration includes a third ${ }^{252} \mathrm{Cf}$ source placed in a well to facilitate easy access for instrument calibration. This source provides a fission spectra partially degraded by the significant scattering from the sides of the well.

\subsubsection{Beta Particle Sources}

Beta particle sources $\left({ }^{204} \mathrm{Tl},{ }^{147} \mathrm{Pm}\right.$, and $\left.{ }^{90} \mathrm{Sr} /{ }^{90} \mathrm{Y}\right)$, obtained from and originally characterized by the Physikalisch-Technische Bundesanstalt (the German NIST equivalent), are maintained primarily for dosimetry characterization. With the exception of ${ }^{147} \mathrm{Pm}$, traceability for these "point" sources has historically been maintained via direct calibration by NIST personnel or via transfer standard intercomparison with NIST. The absorbed dose rate for the ${ }^{147} \mathrm{Pm}$ source was established with adequate confidence, using a laboratory standard extrapolation chamber. However, the source has decayed significantly and provides inadequate dose rates for most uses, including periodic constancy verifications.

Several additional sources of each nuclide are available and have been intercompared to those sources maintained via NIST intercomparison. While these sources contain much the same quantities as the directly traceable sources, some subtleties exist in manufactured geometry and encapsulation. Measurements on some of these sources have been made to verify satisfactory fields in accordance with ANSI N13.11 (1983), DOE/EH-0027 (1986), and ISO 6980, Reference Beta Radiations for Calibrating Dosemeters and Doseratemeters and for Determining Their Response as a Function of Beta Radiation Energy (1984).

\subsubsection{Calibrations and Constancy Checks}

Following initial calibration, and between measurement quality assurance interactions with NIST for most radiation fields maintained by the RS\&C Project, verification measurements are performed to assure constancy of field characteristics and magnitude. For beam- and opengeometry photon fields, abbreviated quarterly checks and generally more rigorous annual verifications are performed. Beta source absorbed dose rates are verified annually, using an extrapolation chamber at fixed distances to assure constancy with original calibration data.

Neutron sources are verified on a quarterly basis, using a laboratory "reference" standard survey instrument. Well sources (photon and neutron) are calibrated annually to provide additional data for modifying the computerized exposure rate calculational program, which determines programmatic instrument calibration points. 
All annual and quarterly calibrations were completed as scheduled in 1992 . The ${ }^{137} \mathrm{Cs},{ }^{60} \mathrm{Co}$, and ${ }^{241} \mathrm{Am}$ photon source calibrations were compared to the eriginally established dose rates corrected for decay. With the exception of quarterly constancy checks performed during the second and third quarters for source $318-027$ (Well $\# 4$ ), all were within $\pm 2 \%$ of those established values (see Table 6.3).

Table 6.3. Photon Reference Fields-Calibration Performance Summary

\begin{tabular}{|c|c|c|c|c|c|}
\hline \multirow{2}{*}{\multicolumn{2}{|c|}{ Source Number }} & \multicolumn{4}{|c|}{ Percent Error of Reference Field Verification } \\
\hline & & Quarter 1 & Quarter 2 & Quarter 3 & Quarter 4 \\
\hline \multirow{7}{*}{${ }^{137} \mathrm{Cs}$} & $318-001$ & -0.212 & $0.150^{(a)}$ & -0.125 & -0.794 \\
\hline & $318-029$ & -0.470 & 0.650 & -0.158 & -0.425 \\
\hline & $318-030$ & -1.037 & $N / A^{(b)}$ & -1.103 & -0.310 \\
\hline & $318-031$ & -0.521 & -1.183 & -0.150 & $\mathrm{~N} / \mathrm{A}$ \\
\hline & $318-040$ & 0.155 & 0.117 & 0.279 & 0.617 \\
\hline & $318-044$ & -0.476 & -0.467 & 0.286 & 0.917 \\
\hline & $318-131$ & 0.603 & 0.211 & 0.042 & 0.050 \\
\hline \multirow{4}{*}{${ }^{60} \mathrm{Co}$} & $318-027$ & $\mathrm{~N} / \mathrm{A}$ & -2.967 & -3.280 & -0.543 \\
\hline & $318-036$ & -0.009 & 0.000 & 0.546 & -0.833 \\
\hline & $318-037$ & 0.170 & 0.183 & 0.487 & -0.883 \\
\hline & $318-164$ & -0.076 & 0.713 & 0.216 & -0.652 \\
\hline${ }^{241} \mathrm{Am}$ & $318-184$ & -0.287 & -0.321 & 0.081 & -1.815 \\
\hline
\end{tabular}

(a) Annual calibrations are shaded.

(b) $\mathrm{N} / \mathrm{A}=$ Not applicable.

Further investigation of Well \#4 constancy verification data indicated that, during the second, third, and fourth quarters, inaccuracies ranging from $-2.48 \%$ to $-6.26 \%$ peaked at, or near, the $3-\mathrm{m}$ source position. This characteristic is indicative of a possible anomaly in the mathematical formula used to correlate exposure rate with source distance in the well. It should be noted, however, that such small discrepancies, while certainly of interest, are not serious and do not pose significant consequences for the overall use of the well. The beta and neutron source measurements that were performed verified absorbed dose and dose equivalent rates, respectively, to within $\pm 2 \%$ of expected values. 


\subsubsection{Measurement Quality Assurance}

As follow-up to measurements performed earlier in 1991, a NIST-owned PTW Model 2047 transmission chamber was exchanged between NIST and PNL. This chamber was used at each facility to assess and intercompare beta reference fields. Only the PTB standards were measured in order to maintain similar spectral and source activity parameters between the two facilities. After resolving problems involving the 1991 data collection at NIST, the intercomparison results were favorable, indicating a maximum deviation of $2.2 \%$. The measurement quality assurance (MQA) results are listed in Table 6.4.

Table 6.4. Beta MQA Performance Summary

\begin{tabular}{cccc}
\hline $\begin{array}{c}\text { Source } \\
\text { (Nuclide/Ref. No.) }\end{array}$ & $\begin{array}{c}\text { Nominal Average } \\
\text { Energy } \\
(\mathrm{MeV})\end{array}$ & $\begin{array}{c}\text { Nominal } \\
\text { Activity } \\
(\mathrm{MBq})\end{array}$ & $\begin{array}{c}\text { Intercomparison } \\
\text { Result } \\
\text { (PNL/NIST) }\end{array}$ \\
\hline${ }^{90} \mathrm{Sr} /{ }^{90} \mathrm{Y}$ & 0.935 & 74 & 0.981 \\
${ }^{90} \mathrm{Sr} / 90 \mathrm{Y}$ & 0.935 & 1850 & 0.985 \\
${ }^{204} \mathrm{Tl}$ & 0.244 & 18.5 & 0.978 \\
\hline
\end{tabular}

Photon MQA intercomparisons, initiated during 1991, were also completed during 1992.

Selected source and $\mathrm{x}$-ray technique measurements were performed at NIST and PNL, using a Capintec PM-30 ionization chamber for photon energies greater than approximately $35 \mathrm{keV}$, and a Precision Radiation Measurement (PRM) LE-0.8 chamber for photon energies of $35 \mathrm{keV}$ or less. The PRM LE- 0.8 chamber was procured during 1991 to serve as a transfer standard to replace a highly stable Victoreen $415 \mathrm{~A}$ low-energy-ion chamber. It is desired to maintain the $415 \mathrm{~A}$ chamber specifically for in-house use because the $415 \mathrm{~A}$ is out of production. The agreement of reference fields using the PM-30 chamber was exceptional, as can be seen in Table 6.5. Fields intercompared using the LE- 0.8 chamber (M30 and M50 x-ray techniques) differed by an average of $4.4 \%$.

Similar results were obtained during follow-up measurements. In reviewing previous MQA results and constancy check data obtained since those intercomparisons were performed, there is no reason to suspect that the fields have altered significantly. It is therefore suspected that the LE-0.8 ionization chamber may not be suitable for such transfer measurements. To further investigate this discrepancy and to complete the MQA process initiated during 1991, current plans include using an Xradin Model A2 chamber, possibly in tandem with the originally used and well-established Victoreen $415 \mathrm{~A}$ chamber. 
Table 6.5. Photon MQA Intercomparison Summary

\begin{tabular}{ccc}
\hline $\begin{array}{c}\text { Source or } \\
\text { X-Ray Technique }\end{array}$ & $\begin{array}{c}\text { Nominal Average Energy } \\
\text { (MeV) }\end{array}$ & $\begin{array}{c}\text { Intercomparison Result } \\
\text { (PNL/NIST) }\end{array}$ \\
\hline${ }^{60} \mathrm{Co}$ & 1.250 & 0.996 \\
${ }^{137} \mathrm{Cs}$ & 0.662 & 0.996 \\
$\mathrm{H} 150$ & 0.120 & 0.994 \\
$\mathrm{M} 150$ & 0.070 & 1.004 \\
$\mathrm{M} 100$ & 0.051 & 1.002 \\
$\mathrm{~S} 60$ & 0.036 & 1.002 \\
$\mathrm{M} 30^{\text {(a) }}$ & 0.020 & 0.986 \\
\hline
\end{tabular}

(a) Independent assessment.

An independent MQA assessment, completed in December and sponsored by NIST in support of the NVLAP dosimetry proficiency testing program, showed the M30 technique to be within $1.4 \%$ agreement.

\subsubsection{Improvements to Standards and Capabilities}

A low-dose calibration-reference field has been established using the ${ }^{137} \mathrm{Cs}$ source contained within Well $\# 1$ (318-031). Exposure rates have been determined as low as $100 \mu \mathrm{R} / \mathrm{h}$, through a lead $(\mathrm{Pb})$ attenuator with the source at the 8-m position. To accomplish the calibration, a $1000 \mathrm{cc}$ Far West Technologies pressurized ion chamber (pressurized to $1 \mathrm{~atm}$ of air) was cross-standardized to the laboratory standard Capintec PM-30 ionization chamber at exposure rates in excess of $1 \mathrm{mR} / \mathrm{h}$. The standardized large-volume chamber then facilitated sufficient current to obtain adequate data within the low-level field. In consideration of the low currents established by this system, particular attention was given to accurately assessing and subtracting leakage current, including associated background. In cases where it exceeded $0.5 \%$ of the total current induced by the ${ }^{137} \mathrm{Cs}$ source, background was re-added to the calibrated fields.

\subsection{SUPPORTING STUDIES}

MQA intercomparisons with NIST for neutron reference fields have been difficult to accomplish due to the lack of a standardized program. The RS\&C Project has experimented with various measurement techniques in the past, with moderate success. However, most of the techniques used, such as thermoluminescent dosimetry (TLD), CR-39 track-etch film, and tissue-equivalent proportional counters (TEPCs), involve highly technical and complex analysis procedures. These procedures are difficult to perform on a frequent and routine basis by personnel without vast experience, while still maintaining an adequate level of accuracy. Recently, Far West 
Technologies developed a TEPC-based survey instrument (REM-500) that has shown potential for use as a valid intercomparison device. The REM-500 survey instrument uses state-of-the-art measurement technology and claims appropriate analysis of the data, using a built-in unfolding code, while maintaining simplicity for the operator. Because of this potential, several measurements of ${ }^{252} \mathrm{Cf}$ neutron reference fields have been made to conduct a draft intercomparison with NIST. A series of measurements were made of the sources in their bare and $\mathrm{D}_{2} \mathrm{O}$ moderated configurations, at varied dose equivalent rates. NIST should complete similar measurements and report their findings during 1993.

During the latter portion of the year, an investigation was initiated to determine the effects of phantom size upon the response of various types of dosimeters exposed to a given neutron dose equivalent. As required by ANSI N13.11 (1983) and DOE/EH-0027 (1986), phantom sizes are currently $30 \mathrm{~cm} \times 30 \mathrm{~cm} \times 15 \mathrm{~cm}$ for photon sources and $40 \mathrm{~cm} \times 40 \mathrm{~cm} \times 15 \mathrm{~cm}$ for neutron sources. Future revisions of these standards may implement $30 \mathrm{~cm}$ x $30 \mathrm{~cm} \times 15 \mathrm{~cm}$ phantoms uniformly for both radiations. The investigation consisted of obtaining a variety of dosimeter styles, including the Hanford badge design and CR-39 track-etch dosimetry, and then irradiating these samples to similar dose equivalents on the two phantom sizes. Results of dosimeter analyses have yet to be reported. It is hoped that no significant difference will be detectable for most dosimeter styles. 


\subsection{HANFORD RADIOLOGICAL RECORDS PROGRAM}

The Hanford Radiological Records Program (HRRP) supports the DOE Richland Field Office (RL) and Hanford contractor radiation protection programs. The HRRP preserves and administers radiological exposure records for all Hanford workers and visitors, past and present. This program is also responsible for maintaining the Hanford Radiation Protection Historical Files. Program personnel operate the computer systems and library equipment necessary for inputting, storing, and retrieving the records, and for producing the required reports.

The HRRP uses the Occupational Radiation Exposure (ORE) system, which includes a database containing the personnel exposure data. These data are readily retrievable via a system of personnal computers (PCs) and terminals. ORE also includes all of the supporting exposure documentation on microfilm, which is indexed into a computer-assisted retrieval (CAR) system. The CAR system allows for rapid retrieval of the documents for any individual, through the use of identifiers such as payroll number, social security number, and/or name. During 1992, a new records database system, called the Radiological Exposure (REX) system, was under development on a different mainframe computer to replace ORE. A database administration function performs system evaluations, troubleshooting, resolution of system and user problems, training of users, oversight of system security, and initiation and testing of modifications to the database.

The historical records include documents, such as policies, procedures, reports, and important communications, that define the Hanford radiological dosimetry and radiation protection programs during its history. The historical records are microfilmed and indexed into a second CAR system. These records are retrievable by author, date (or range of dates), document number (if applicable), title, and up to three keywords.

The program is operated under the applicable sections of ANSI N13.6, American Standard Practice for Occupational Radiation Exposure Records Systems (1972), and the Hanford Site Radiological Control Manual, HSRCM-1 (RL 1992), as well as under the following DOE Orders (as assigned by the Hanford Site Services Handbook $\left.{ }^{(\mathrm{a})}\right)$ : 1300.1, "Micrographic Management" (1980); 1324.2A, "Records Disposition" (1988); 5480.11, "Radiation Protection for Occupational Workers" (1990); and 5484.1, "Environmental Protection, Safety, and Health Protection Information Reporting Requirements" (1987a). The program also complies with the applicable sections of the Privacy Act (1974) and the Freedom of Information Act (1966).

(a) U.S. Department of Energy Richland Field Office (RL), 1993, RL 1400.1A, Richland, Washington (available online in HanInfo). 


\subsection{THE ROUTINE PROGRAM}

The HRRP is organized into three major functional areas: data processing, report issuance, and the library. Both data handling and report issuance are performed by the Radiological Records Data Processing Center.

Data processing includes entering data into the ORE database and validating all data entry. Validation is accomplished by establishing audits to be matched to entries of results, resolving unmatched results, and interacting directly with contractor personnel. Data processing also includes dealing directly with the contractor personnel and data suppliers to assist them and solve data problems. This function requires close contact with the RL, the Hanford contractors, and other personnel dosimetry functions.

The report issuance function generates and issues the following reports:

- $\quad$ routine exposure-status reports to the contractors;

- $\quad$ quarterly manrem and annual statistical reports to DOE;

- annual reports to employees;

- $\quad$ special reports requested by former employees; and

- $\quad$ special reports requested by the contractors and the RL.

The library maintains individual exposure records that are not reducible to database elements, as well as the Hanford Radiation Protection Historical Files. The library staff file and retrieve current hardcopy documents, prepare documents for long-term storage, and track and account for the documents through the microfilming and indexing process. The library contains the individual exposure records of all Hanford personnel since 1945 (almost five-million microforms). There are also some exposure records remaining from the Hanford duPont era. These and the Historical Files microforms are retrievable through two CAR systems maintained by the library staff. At year end, a laser optical disk (LOD) subsystem to REX (called LaserREX) was installed to replace the exposure record microfilm storage methodology. In addition to providing individual exposure data, the Program provides data for epidemiology projects, research projects, and litigation support.

Although the results of dosimeter and excreta processing, as well as the in vivo counts, are received by electronic transmission or magnetic tape, a large amount of data is received in hardcopy form. These data are entered manually by the Data Processing Center staff and then sent to the library in hardcopy form for entry into the CAR system. Table 7.1 presents CY 1992 statistical information on many of the documents entered into the database and then microfilmed and indexed into the CAR system. 
Table 7.1. Records Activity for 1992

\begin{tabular}{ll}
\hline \multicolumn{1}{c}{ Document } & Number \\
\hline $\begin{array}{l}\text { Personal Radiation Exposure History Form (used to document exposure } \\
\text { history prior to Hanford) }\end{array}$ & 4,508 \\
$\begin{array}{l}\text { Employee and Dosimetry Change Forms (used to document } \\
\text { personnel or dosimetry changes) }\end{array}$ & 5,799 \\
$\begin{array}{l}\text { Employee and Dosimetry Change Forms (used to document } \\
\text { employee terminations) }\end{array}$ & 2,978 \\
$\begin{array}{l}\text { Temporary Dosimeter Assignment Forms (used for visitors and } \\
\text { subcontractors, as well as for employees who forgot their dosimeters) }\end{array}$ & 23,807 \\
$\begin{array}{l}\text { Investigation of Dosimeter Result Forms and Change Letters (used to } \\
\text { estimate exposure for lost, damaged, or otherwise suspect dosimeter } \\
\text { results) }\end{array}$ & 1,708 \\
$\begin{array}{l}\text { Special Process Forms (used to document data for specially processed } \\
\text { dosimeters) }\end{array}$ & 3,312 \\
$\begin{array}{l}\text { Request for Special Excreta Sample Analyses (used to initiate the } \\
\text { collection of samples for analysis) }\end{array}$ & 3,805 \\
$\begin{array}{l}\text { Requests for Exposure Summaries (summaries requested for current and } \\
\text { prior Hanford employees) }\end{array}$ & 1,488 \\
$\begin{array}{l}\text { Letters Sent to Request Prior Exposure (to request summaries for new } \\
\text { employees with prior exposure) }\end{array}$ & 1,114 \\
$\begin{array}{l}\text { Microfilm Reels Indexed into CAR (personnel and historical documents; } \\
\text { each reel contains over 2000 images) }\end{array}$ & 30 \\
\hline
\end{tabular}

A set of internal desk procedures is being developed for the program. The first manual in this set, Dosimetry Records Library Desk Procedures, ${ }^{(a)}$ was completed in 1992 . The desk procedures for the Data Processing Center and database administration function supporting REX have yet to be developed.

Because a replacement for ORE was being developed, changes to the database during the year were limited to those necessary to keep the system functional, those required by additions or changes to DOE orders, or those that reduce costs. New data lines were also installed, and the system was prepared to receive data from the new International Technology Analytical Services (ITAS) laboratory. A few minor changes were made to respond to the newly published HSRCM-1 (RL 1992).

(a) Internal manual, Pacific Northwest Laboratory, Richland, Washington. 


\subsection{SUPPORTING TASKS}

HRRP supporting tasks included developing REX and an LOD subsystem called LaserREX.

\subsubsection{Development of the REX System}

Allocations were received in fiscal year (FY) 1990 for starting the development of REX, the ORE replacement system. Allocations for continuing the project were received in FY 1991, FY 1992, and FY 1993. The effort was envisioned to take over three years and consist of four main phases.

\subsubsection{REX Development Phases}

As originally conceived, the four phases of REX development were

1. Systems Requirements Analysis - The requirements for the new system were defined in this step. The analysis involved interaction with all the users and data suppliers to determine their needs. From this effort, a requirements document was produced that was used as the basis for designing and constructing the new system.

2. Preliminary Design - This step, which was based on the requirements analysis, included the development of the functional specifications for the new system, an analysis of alternatives, and the production of an alternatives analysis document. The alternatives analysis would determine the hardware/software application that best suited the requirements. This phase also included the final cost/benefit analysis, as well as schedules and plans for the detailed design and construction, verification, installation, and start-up phases.

3. Detailed Design and Construction - This phase, which included the detailed design and programming of the new system defined in the previous two phases, was expeeted to take at least 12 months. The detailed design portion included tasks such as the functional system design; program design; design testing and analysis; development of system test, certification test, and acceptance test plans; and development of a conversion plan and a training plan. The construction portion included tasks such as coding; unit, integration, and system testing; and development of conversion and acceptance test materials.

4. Certification and Implementation - This phase included converting data from the old to the new system, certifying correct installation, and training users. Correct installation was to have been verified by modular, integration, and system testing. Once testing had shown that the new system met the acceptance criteria, parallel runs of the new system were to have been conducted with the old ORE system. Following a successful parallel run, the new system was to have been established as the production system. 
The first phase of the REX development effort, System Requirements Analysis, was completed during CY 1990. The second phase, Preliminary Design, was started during 1990 and continued into 1991. The Detailed Design and Construction phase was started in 1991 and continued through the end of the 1992. The final phase, Certification and Implementation, was started during 1992 and was being continued at year end.

\subsubsection{REX Development Activities}

In 1992, detailed data flow and entity relationship diagrams were produced, along with a data dictionary. Revision 0 of the Software Design Document (SDD) and the Acceptance Test Plan were completed. The SDD lists 151 different screens, 72 reports/report screens, and 21 interfaces. Conversion business rules and the Conversion Plan were also produced. The initial trial conversion, which was a partial conversion, included three million records. Rejects, which were minimized by user involvement, were identified and corrected. The converted data was used as the test database, allowing testing with real data.

The original implementation date of November 1992 was found to be unacceptable because HRRP and contractor dosimetry staffs would be involved in year-end processing. Because this processing requires considerable extra effort, including overtime, it was decided that the personnel could not be trained and ready to work on a new system by December. The implementation date was rescheduled for March 1993.

All HRRP staff (particularly the database administrator and records specialist), as well as contractor dosimetry records personnel, were involved in the design and implementation effort. There has been a high degree of user input to the project. At year end, integration testing was being conducted. Some report design, final coding, and modifications based on testing remained to be completed.

\subsubsection{REX Features}

REX contains several innovations that were not part of ORE. A transaction log has been designed to record changes to the database, resulting in the use of fewer paper forms. The transaction $\log$ records, separately from the actual change, the name of the individual who made the change, the date it was made, the type of change (e.g., change in name, dose, or dosimeter or bioassay frequency), the original value, and the new value. The log is stored on the laser optical disk (LOD) system discussed in section 7.2.2.

An additional unique feature is a help function. The database contains over 50 different types of codes. If operators cannot remember the proper code to be entered, they can place the cursor on the code field, and then press the F1 function key to display a table of all the applicable codes. Each type of code has its own table. 
Because REX was built using IBM relational database management software (DB2 DBMS) that includes the Standard Query Language (SQL), ad hoc reports are easier to produce. A software package for writing reports, Platinum Report Facility (PRF), has been added to make the process even easier.

The database contains exposure records for individuals with more than one social security number, as well as some early records for individuals who had no social security number. Because of these problems, REX generates a unique identification number (the REX ID) for each individual in the database.

\subsubsection{Laser Optical Disk Subsystem}

REX was designed around the use of electronic transaction records, so fewer paper records will be needed. Instead of storing these records in the database, which can use considerable capacity and be costly, they will be stored on an LOD subsystem. Electronic records will be transferred regularly from the LSIS computer and recorded on write-once/read-many (WORM) laser optical disks. In addition, paper records can be scanned and recorded on the disks. All records will be indexed into a database for automated retrieval.

The LOD subsystem, shown in Figure 7.1, was procured and installed during 1992. Testing and training of the operators was in progress at year end. The subsystem, which is WINDOWS based, has two interfaces with REX. One interface is the downloading the transaction log data discussed previously. The second interface allows verification of individual identifiers against the REX identification tables during indexing of the hardcopy documents.

The transaction log data will be automatically indexed to the individual involved. Retrieval will be by individual identifiers, record type, and date. When retrieved, the data will be inserted into a template so that the data is understandable and the items are identified.

\subsection{PROGRAM-RELATED PROFESSIONAL ACTIVITIES}

Staff presentations, publications, and professional memberships during 1992 are listed in this section.

\subsubsection{Presentations}

Berndt, V. L. 1992. "Can't Justify an Imaging System? How About a CAR?" Presented at the Region X Conference of the Association of Records Managers and Administrators, May 26-29, 1992, Anchorage, Alaska. 


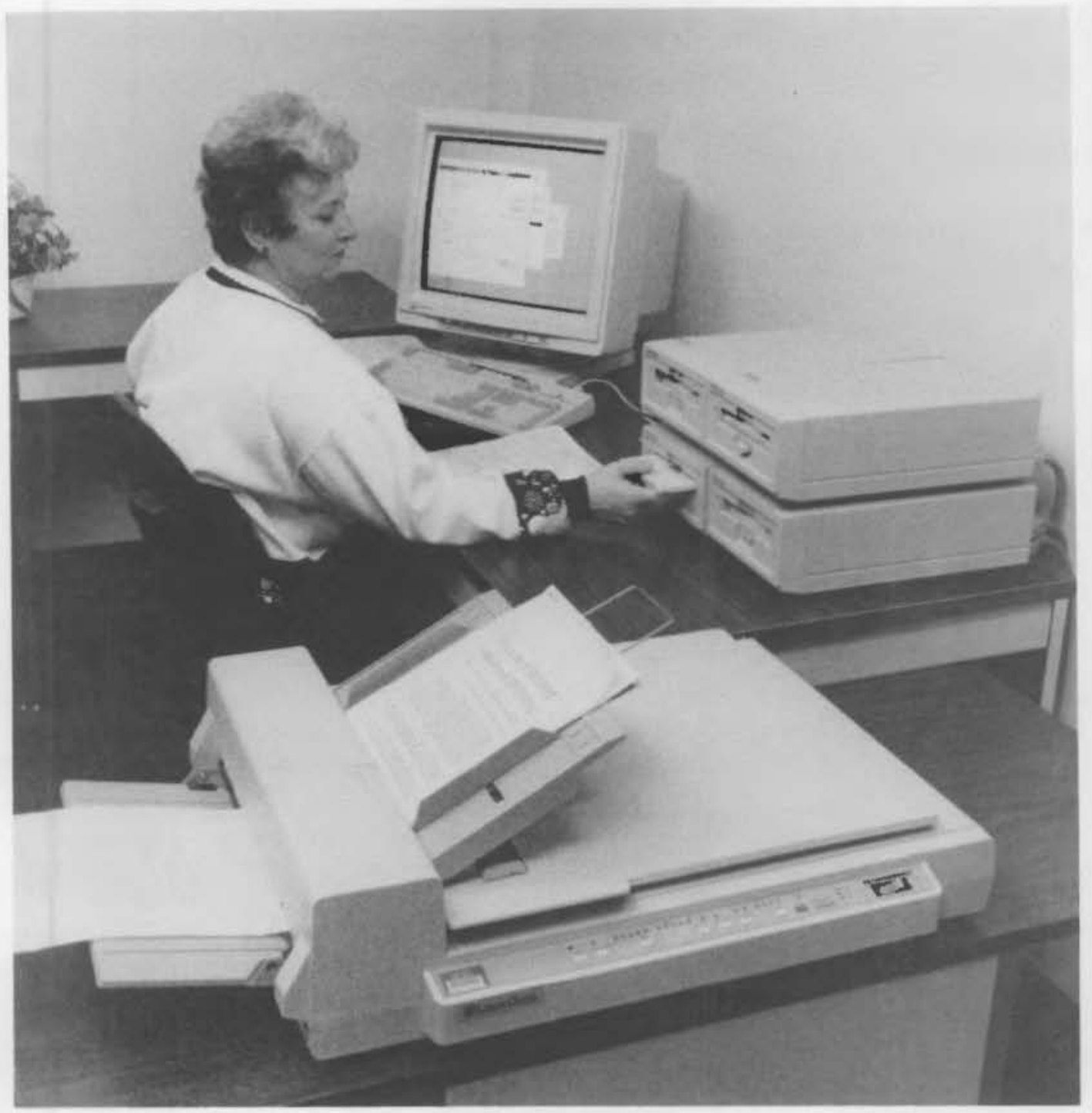

Figure 7.1. The Laser Optical Disk Subsystem. Shown here are the document scanner (foreground), the optical disk drives (being loaded), and the special dual document monitor. 


\subsubsection{Publications}

Lyon, M. 1992. Draft U.S. Department of Energy Implementation Guide 8.1, Occupational Radiological Exposure Record-Keeping and Reporting. Pacific Northwest Laboratory, Richland, Washington.

Lyon, M., and J. B. Martin. 1992. "Computerizing Occupational Protection Records Systems." Nucl. Plant J. 10(3):92-96.

\subsubsection{Professional Memberships}

Lyon, M. Chairman of the Health Physics Society Standards Committee Working Group to review ANSI N13.6, American Standard Practice for Occupational Radiation Exposure Records Systems.

Lyon, M. Chapter Coordinator for Records and Reports for the DOE Radiological Control Manual Working Group. 


\subsection{REFERENCES}

American National Standards Institute (ANSI). 1983. American National Standard for Dosimerry - Personnel Dosimetry Performance - Criteria for Testing. ANSI N13.11, New York.

American National Standards Institute (ANSI). 1978. Radiation Protection Instrumentation Test and Calibration. ANSI N323, New York.

American National Standards Institute (ANSI). 1972. American Standard Practice for Occupational Radiation Exposure Records Systems. ANSI N13.6, New York.

Baumgartner, W. V., A. W. Endres, and S. R. Reese. 1992. Quality Control Program for the Hanford External Dosimetry Thermoluminescent Processing System. PNL-8299, Pacific Northwest Laboratory, Richland, Washington.

Brackenbush, L. W., W. V. Baumgartner, and J. J. Fix. 1991. Response of TLD-Albedo and Nuclear Track Dosimeters Exposed to Plutonium Sources. PNL-7881, Pacific Northwest Laboratory, Richland, Washington.

Fix, J. J., E. S. Gilbert, R. H. Wilson, W. V. Baumgartner, and L. L. Nichols. 1992. "Comments on 'Evidence of Biased Recording of Radiation Doses of Hanford Workers.'" Am. J. Indust. Med. 22:281-283.

Freedom of Information Act. Public Law 89-487, July 4, 1966.

Gibson, J. A., A. Birchall, R. K. Bull, K. Henriche, E. Iranzo, D. J. Lord, J. Piechowski, E. Sallett, N. P. Tancock, and C. A. Werali. 1992. "A European Intercomparison of Methods Used for the Assessment of Intakes of Internally Deposited Radionuclides." Radiat. Prot. Dosim. 40(4):245-257.

International Standards Organization (ISO). 1984. Reference Beta Radiations for Calibrating Dosemeters and Doseratemeters and for Determining Their Response as a Function of Beta Radiation Energy. ISO 6980, Geneva.

La Bone, T. R., E. H. Carbaugh, W. C. Griffith, R. A. Guilmette, and K. W. Skrable. 1992. Evaluation of Savannah River Site Internal Dosimetry Registry Case 664(U). ESH-HPT-920178, Westinghouse Savannah River Company, Savannah River Site, Aiken, South Carolina.

Lyon, M., and J. B. Martin. 1992. "Computerizing Occupational Protection Records Systems." Nucl. Plant J. 10(3):92-96.

Lyon, M., D. E. Bihl, J. J. Fix, R. K. Piper, T. J. Froelich, J. A. Leonowich, and T. P. Lynch. 1992. Hanford Radiological Protection Support Services Annual Report for 1991. PNL-8236, Pacific Northwest Laboratory, Richland, Washington. 
Mays, C. W., R. L. Aamodt, K. G. Inn, D. R. Brown, R. R. Greenburg, V. G. Iyengar, F. J. Schima, L. S. Slaback, J. W. Tracy, T. P. Lynch, and K. L. Mossman. 1992. "External Gamma-Ray Counting of Selected Tissues from a Thorotrast Patient." Health Phys.

63(1):33-40.

Privacy Act, 44 Federal Regulations 510772 (1974).

Sula, M. J., E. H. Carbaugh, and D. E. Bihl. 1991. Technical Basis for Internal Dosimetry at Hanford. PNL-6866.R1, Pacific Northwest Laboratory, Richland, Washington.

U.S. Department of Energy (DOE). 1992. U.S. Department of Energy Radiological Control Manual. DOE/EH-0256T, Washington, D.C.

U.S. Department of Energy (DOE). 1990. "Radiation Protection for Occupational Workers." DOE Order 5480.11, Washington, D.C.

U.S. Department of Energy (DOE). 1988. "Records Disposition." DOE Order 1324.2A, Washington, D.C.

U.S. Department of Energy (DOE). 1987a. "Environmental Protection, Safety, and Health Protection Information Reporting Requirements." DOE Order 5484.1, Washington, D.C.

U.S. Department of Energy (DOE). 1987b. "U.S. Department of Energy Laboratory Accreditation Program for Personnel Dosimetry." DOE Order 5480.15, Washington, D.C.

U.S. Department of Energy (DOE). 1986. Department of Energy Standard for the Performance Testing of Personnel Dosimetry Systems. DOE/EH-0027, Washington, D.C.

U.S. Department of Energy (DOE). 1980. "Micrographics Management." DOE Order 1300.1, Washington, D.C.

U.S. Department of Energy Richland Field Office (RL). 1992. Hanford Site Radiological Control Manual. HSRCM-1, Richland, Washington. 


\section{DISTRIBUTION}

No. of

Copies

\section{OFFSITE}

12 DOE/Office of Scientific and Technical Information

DOE Albuquerque Field Office

J. B. Martin

Battelle Pantex

Pantex Plant

P.O. Box 30020

Amarillo, TX 79120

L. M. Coco

Mound Laboratory

EG\&G

Mound Applied Technologies

P.O. Box 3000

Miamisburg, $\mathrm{OH} 45342$

J. M. Graf

Los Alamos National Laboratory

P.O. Box 1663

Los Alamos, NM 87545

R. M. Rogers

EG\&G Rocky Flats

Rocky Flats Plant

P.O. Box 464

Golden, CO 80402-0464

DOE Chicago Field Office

A. E. Keuhner

Brookhaven National Laboratory

Upton, NY 11973
No. of

Copies

R. E. Toohey

Argonne National Laboratory 9700 South Cass Avenue

Argonne, IL 60439

DOE Idaho Field Office

H. D. Christiansen

Westinghouse Idaho Nuclear

Company, Inc.

P.O. Box 4000

Idaho Falls, ID 83404

DOE Nevada Field Office

B. P. Smith

Reynolds Electrical and

Engineering Co., Inc.

P.O. Box 98521

Las Vegas, NV 89193

DOE Oak Ridge Field Office

J. S. Bogard

Oak Ridge National Laboratory

Martin Marietta Energy

Systems, Inc.

P.O. Box 2008

Oak Ridge, TN 37831

J. B. Hunt

Y-12 Plant

Martin Marietta Energy

Systems, Inc.

P.O. Box 2008

Oak Ridge, TN 37831

Distr.1 
No. of

Copies

DOE San Francisco Field Office

C. T. Prevo

Lawrence Livermore National Laboratory

P.O. Box 808

Livermore, CA 94550

DOE Savannah River Field Office

D. A. Stevenson

Westinghouse Savannah River

Company

Savannah River Plant

P.O. Box 616

Aiken, SC 29802

\section{ONSITE}

4 DOE Richland Operations Office
R. F. Brich
D. L. Clark
D. T. Evans
R. A. Holten

2 Hanford Environmental Health Foundation

R. H. Ronish

M. J. Swint

Kaiser Engineers Hanford

D. J. Foust

3 Westinghouse Hanford Company

W. A. Decker, Jr.

R. E. Heineman

T. J. Kelly
No. of

Copies

Washington State University

(Tri-Cities)

R. L. Kathren

40

$\underline{\text { Pacific Northwest Laboratory }}$

D. E. Bihl (2)

D. M. Fleming

J. J. Fix (2)

T. J. Froelich (2)

D. P. Higby

G. R. Hoenes

J. R. Houston (2)

J. R. Johnson

M. Lyon (10)

T. P. Lynch (2)

J. C. McDonald

I. C. Nelson

R. K. Piper (2)

B. A. Rathbone

K. L. Soldat

K. L. Swinth

R. A. Walters

Publishing Coordination

Technical Report Files (5)

Radiation Protection

Historical Files

(c/o V. L. Berndt) (2) 